\title{
Sustaining Group Reputation
}

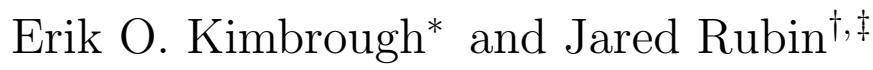

May 2, 2013

\begin{abstract}
When individuals trade with strangers, there is a temptation to renege on contracts. In the absence of repeated interaction or exogenous enforcement mechanisms, this problem can impede valuable exchange. Historically, individuals have solved this problem by forming institutions that sustain trade using group, rather than individual, reputation. Groups can employ two mechanisms to uphold reputation that are generally unavailable to isolated individuals: information sharing and in-group punishment. In this paper, we design a laboratory experiment to distinguish the roles of these two mechanisms in sustaining group reputation and increasing gains from trade. We find that information sharing encourages path dependence via group reputation; good (bad) behavior by individuals results in greater (fewer) gains from exchange for the group in the future. However, the mere threat of in-group punishment is enough to discourage bad behavior, even if punishment is rarely employed. When combined, information sharing and in-group punishment work as complements; the presence of ingroup punishment encourages cooperation early on, and information sharing reinforces this behavior over time.
\end{abstract}

JEL Classifications: C9, D02, D7, Q2

Keywords: Experimental Economics, Group Reputation, Information, Group Punishment, Gains from Trade, Trust Game, Juries

*Corresponding Author: Department of Economics, Simon Fraser University, 8888 University Drive, Burnaby, BC, Canada, ekimbrough@gmail.com.

$\dagger$ Argyros School of Business and Economics, Chapman University, One University Drive, Orange, CA, USA, jrubin@chapman.edu.

${ }^{\ddagger}$ Acknowledgements: We thank Dominic Donato for skillfully programming our virtual world and Jennifer Cunningham for assistance in running the sessions. Funding was provided by a grant from the John Templeton Foundation. Some figures in this paper were created using the open-source statistics software R (R Development Core Team, 2012). The software, source code, and data are available upon request and upon acceptance by a journal. 


\section{Introduction}

Most trade is sequential. One party receives goods or money and then gives the other party something in return. This means that, absent any enforcement mechanism, the second party has incentive to renege on the original agreement. Knowing this, the first party will not enter into the trade arrangement in the first place, and potential welfare gains are lost.

In order for both parties to be willing to engage in trade, they must be able to commit ex ante to fulfilling their end of the bargain ex post (Greif, 2000, 2006). This problem is solved today in many parts of the world with well-functioning legal, judicial, and penal institutions that impartially convict and punish cheaters. Such institutions are costly to build, however, and they are clearly not the only solution (Dixit, 2004); after all, trade predates the emergence of these types of institutions by millennia (see e.g. Cunliffe, 2008).

Repeated interaction is one solution for sustaining trade in the absence of third-party enforcement (Fudenberg and Maskin, 1986). When the discounted gains from future encounters exceed the gains from reneging in the present, both parties will willingly trade. Yet, there are many circumstances under which repeated interaction cannot sustain trade. If individuals have many options for trade partners and information about their past actions is not available, the incentive to cheat can outweigh the returns from repeated relationships, since the cheating party cannot be punished in the future (Ghosh and Ray, 1996; Kranton, 1996).

Under these circumstances, trade is unlikely to occur unless some type of reputationbased or punishment institution is present. Reputation building can encourage trade by linking past actions to future rewards. The Maghribi Traders' Coalition studied by Greif (1993, 2006) provides an excellent example of how such an institution can facilitate trade through a mechanism allowing agents to build individual reputations. Yet, a problem with institutions based on individual reputation is that they are expensive to build and maintain. 
Information about each individual's past actions must be collected and traders must be monitored to ensure that they abide by the rules governing the institution.

Since information on individual reputation is costly to collect, a common solution for facilitating exchange is the establishment of institutions meant to create and sustain group reputation. Institutions that rely on group reputation have a clear advantage over those that rely on individual reputation or those that rely on formal legal and penal institutions: it is much less expensive to collect and disseminate information on group reputation. Instead of having to obtain information about past actions of each individual trade partner, all one has to know about a counterpart is their group identity and whether any of their group members have cheated in the past. This makes group reputation an attractive mechanism to facilitate trade (Ghatak and Guinnane, 1999).

Yet, institutions based on group reputation can be costly in other ways. In particular, there is a cost that arises from the tension between individual and group incentives: individuals impose a negative externality on their group members when they cheat, since they damage the reputation of the entire group (Tirole, 1996; Winfree and McCluskey, 2005; Levin, 2009). In the absence of strong institutional or social sanctions, there is little incentive for group members to internalize the externality that their actions impose on fellow group members.

How do groups overcome this problem and align the incentives of the individual with those that are best for the group? Historically, groups formed institutions that promoted enforcement through in-group punishment. ${ }^{1}$ One example of such an institution was the community responsibility system (CRS) used by medieval European trading cities. In this institution, all traders from an entire merchant community were punished for a transgression by any one of their group members (Greif, 2002, 2004; Boerner and Ritschl, 2009). The key

\footnotetext{
${ }^{1}$ For a broad historical overview, see Levinson (2003). For a theoretical analysis of enforcement of group reputation enhancing norms via in-group sanction, see Kandori (1992).
} 
institutional feature of the CRS was a system of courts that encouraged groups to punish cheaters within their own group in order to uphold the group's reputation. Similar in-group punishment mechanisms were used by medieval merchant guilds (Milgrom et al., 1990; Greif et al., 1994) and craft guilds (Richardson, 2005; Richardson and McBride, 2009). Group reputation was important to both types of guilds since their access to markets depended on it.

Institutions that sustain exchange and cooperation through in-group punishment are also widespread in the modern world. An important example comes from microfinance, where most loans are based on joint liability, and co-signing peers encourage compliance through social sanctions (Besley and Coate, 1995; Ghatak and Guinnane, 1999; de Aghion, 1999). Fearon and Laitin (1996) provide an example from political science, arguing that one reason that inter-ethnic conflict is the exception rather than the rule is that ethnic groups have significant incentive to punish transgressors from their own group, since doing so maintains the group's reputation and helps avoid conflict. Legislative politics provides yet another example of widespread in-group punishment. Since individual politicians' reputations are also tied to the reputation of their party, party leaders often reward and punish with committee memberships and other resources in order to encourage individual actions consistent with the objectives of the group (Cain et al., 1987; Katz and Sala, 1996). ${ }^{2}$

Recent theory and experimental evidence suggests that another mechanism besides ingroup punishment is available to groups to encourage individuals to uphold group reputation: information sharing. Specifically, we mean in-group sharing of information about individuals' past interactions with other groups. If members of Group A know how their fellow members were treated by those in Group B, Group B quickly gains a reputation with all

\footnotetext{
${ }^{2}$ More generally, there are a host of business practices as well as features of political institutions that facilitate the establishment and maintenance of group reputation (Seabright, 1993; Bar-Isaac, 2007; Evans and Guinnane, 2007). Winfree and McCluskey (2005) note, however, that such mechanisms are not always available, especially in larger groups.
} 
members of Group A, not just those with whom they interacted. This increases the costs of cheating for Group B members since it reduces potential future gains from trade with all of Group A. While these increased costs of cheating are not always enough to induce a purelyselfish, money-maximizing individual to act in a manner that upholds group reputation (at the expense of individual gain), Healy (2007) shows that if there is a sufficient percentage of pro-social, reciprocal types ${ }^{3}$ and individuals have a sufficiently low discount rate, the incentives to preserve group reputation can encourage even selfish types to sustain cooperation through the penultimate interaction. Healy's result hinges on the assumption that some degree of "stereotyping" occurs in anonymous settings; individuals don't actually know the "types" of the people they are dealing with, so they update their beliefs by assuming that all individuals from a cheater's group are likely cheaters. This theoretical construct should be exacerbated when groups are able to share information, since stereotyped beliefs spread quicker throughout the population.

In most real-world settings where in-group punishment is used to uphold group reputation, there is some degree of information sharing within groups; this is certainly true of the historical institutions noted above (the CRS and guilds) as well as contemporary institutions such as microfinance and political parties. Since both information sharing and in-group punishment can work to sustain group reputation, it is not clear ex ante whether both are necessary or how they interact when both are present. Our paper addresses this problem with an experiment aimed at parsing out the roles that in-group punishment and information sharing play in sustaining group reputation. In our experiment, subjects play a repeated trust game (as in Berg et al., 1995) with pre-play, cheap-talk communication and random rematching where group identity, but not individual identity, is known. This creates a situation similar to those described above in which parties have incentives to "cheat" and

\footnotetext{
${ }^{3}$ In a variety of well-known experiments, individuals exhibit extensive pro-social behavior (see Cooper and Kagel, 2013, for a summary).
} 
individual reputation mechanisms are infeasible. We employ a $2 x 2$ experimental design varying, 1) whether receivers have access to a jury system, through which group members can vote to punish cheaters in their own group (in-group punishment), and 2) whether subjects are given information on how others in their group fared (information sharing).

Our design allows us to distinguish whether and how the two mechanisms of sustaining group reputation influence behavior in an environment where individual reputation concerns are absent. Specifically, because individuals trade with members of two different groups, with whom they typically have different histories of interaction, we can identify the effects of both mechanisms by decomposing history-dependence into session-wide and group-specific components. In other words, we demonstrate the importance of group reputation by examining whether individuals treat members of a group differently according to both their own and their group members' history of interaction with that group.

Previous experimental work on cheating in trade has demonstrated that the opportunity to cheat substantially reduces the gains from exchange (Cassar et al., 2009), and additional work emphasized the power of information-sharing to facilitate individual reputationbuilding to reduce the likelihood and cost of cheating (Cassar et al., 2010). Similarly, individual reputation-building has been shown to encourage trust and reciprocity in repeated trust games, both in repeat dyadic interaction and in interactions with strangers whose reputations are known (Bohnet and Huck, 2004). Group reputation has also received some recent attention in the lab. In addition to Healy (2007), who establishes the effectiveness of group reputation in encouraging cooperation in a labor market experiment, Huck and Lünser (2010) report an experiment with repeated extensive form trust games comparing a situation where subjects receive information about about the play of the individual with whom they are matched to one where they only receive information about the behavior of the matching group as a whole. They find some evidence that group information is a substitute for individual information in small groups and can encourage the gains from exchange. Similarly, 
McIntosh et al. (forthcoming) report a public goods game where individuals are assortatively matched over time according to either individual past behavior or the past behavior of their group. They too find that individual and group information are substitutes.

Our experiment differs from previous work in that we explore the separate and joint impact of two mechanisms that use group reputation to facilitate cooperation. We not only show that these mechanisms work, but why they work. We find that both information-sharing and in-group punishment can increase welfare relative to a baseline where neither is available. Moreover, when both are present, they act as complements, further increasing welfare gains. With information, individuals are able to tailor their behavior not only to their own history of interaction but also to that of their group members - expanding trade when it has been successful and restraining it when previous efforts led to cheating. Information sharing therefore accentuates path-dependence and aligns individual behavior with the incentives faced by the group. Unlike information sharing, in-group punishment works by reducing the incentives to cheat in the first place. Knowing that they may be punished by their group members, individuals cheat much less in the jury treatments, regardless of the past actions of the juries. ${ }^{4}$ Thus, the complementarities are obvious: the presence of in-group punishment encourages cooperation early on, and information sharing reinforces this behavior over time. This is perhaps a primary reason why groups that rely on in-group punishment to sustain group reputation also frequently share information within their groups (both historically and contemporarily). Information sharing reinforces the gains made via in-group punishment.

\section{Experimental Design}

We employ a 2x2 experimental design to explore the impact of group information (Info) and in-group punishment (Jury) on the gains from exchange in repeated investment trust games

\footnotetext{
${ }^{4}$ We do find that individuals cheat even less when they have been convicted in the past. Regardless, there is a clear treatment effect independent of previous actions.
} 
with pre-play communication and random rematching (see Berg et al. (1995) for the classic reference on investment trust games). Subjects know the group identity of the subject they are matched with, but not the individual identity.

In the baseline treatment (No Jury - No Info), subjects have no access to the jury to enforce contracts and can only acquire group reputation information through their own experience. Sixteen subjects are each initially randomly assigned a color (red or blue) and a role (sender or receiver), which they maintain throughout an entire 10-period session. Subjects were not told which period the game would end, and the game ended more than 30 minutes before the allotted time slot, so we expect there to be no endgame effects. In total there are eight subjects of each color, and of those eight, four are senders and four are receivers. At the beginning of each period, a randomly paired sender and receiver learn the color of their counterpart and are endowed with 10 experimental currency units (ECU). The sender can choose to send any integer amount between 0 and 10 ECU to the receiver, knowing that the amount sent will be multiplied by 3 and given to the receiver. The receiver then chooses to send back to the first mover any amount between 0 and the amount received. At the end of the period, the sender earns $(10-$ ECUs sent to the receiver + ECUs returned from the receiver $)$ and the receiver earns $(10+$ ECUs sent from the sender - ECUs returned to the receiver).

Prior to the sender's decision, the receiver has the opportunity to send a non-binding message stating "I will return X\% of the total amount that I receive." The receiver may either choose an integer X between 0 and 100 and send the message, or click a button indicating that she does not want to send a message. The sender then reads the message (or reads that the receiver has chosen not to send a message) and makes her decision. The receiver then sees a message indicating the promised return, given the message she sent, and chooses how much to return. Finally, both parties are informed about their final payoffs as well as whether the amount that the receiver would return if she fulfilled the message 
she sent. Crucially, the message allows both subjects and experimenters to clearly define instances of "cheating". The message can be viewed as an informal contract, and the contract is violated by any receiver returning less than promised in the message.

It should be clear that the subgame perfect Nash equilibrium of the game is for the sender to send nothing because the receiver has a dominant strategy to keep the whole amount sent. Nevertheless, it is well known that individuals regularly send substantial amounts in oneshot trust games, and receivers typically return at least some portion of what they receive. There are potential gains from exchange, and trusting behavior by the first mover is often rewarded with reciprocity by the second mover. Moreover, there is extensive evidence that "cheap talk" can encourage such behavior (e.g Charness and Dufwenberg, 2006; Bohnet and Baytelman, 2007; Ben-Ner and Putterman, 2009; Balliet, 2010).

Thus, our baseline treatment provides us with estimates of the gains from exchange with cheap talk contracting when individuals have only private information about previous interactions with blue and red counterparts. Our other treatments vary 1) the amount of information subjects receive about the outcomes of others in their group and 2) access to the jury contract enforcement mechanism.

In the No Jury - Info treatment, the procedures are identical to the No Jury - No Info treatment except that, at the conclusion of each period, subjects also receive information about what happened to each other player of the same color and type. ${ }^{5}$ For example, all blue senders learn the following information about each other blue sender at the end of the period: 1) the color of their matched receiver counterpart; 2) the message sent; 3) the number of ECUs sent; 4) the amount the receiver would need to return to satisfy the message sent; 5) how many ECUs were actually returned; and 6) the sender's earnings. This models an information sharing agreement among members of group who, at the conclusion

\footnotetext{
${ }^{5}$ This technique is similar to that applied in Cassar et al. (2010), where information is shared within trading networks but not between them.
} 
of each transaction, report the details to others in the group. Alternatively, it also models a small-group setting, where information about the actions of all other group members is easily attainable. Note that this information does not change the subgame perfect Nash equilibrium of the stage game, but by providing richer information about the actions taken by others of the same type and their counterparts, it may help shape agents' beliefs about the actions that will be taken by their future counterparts. In other words, in this relatively small world (with 8 potential trading partners) the richer information set produced by the No Jury - Info treatment allows agents to more accurately assign a reputation to each group.

The Jury - No Info treatment is also identical to the No Jury - No Info treatment with one exception. At the conclusion of each transaction, senders review the outcome and compare the amount returned by the receiver to the amount "promised" in the message. If the amount returned is less than promised, the sender has the option of appealing to a jury of the receiver's peers to attempt to force the receiver to pay the remaining amount. Specifically, if a sender seeks restitution, he incurs a cost of $2 \mathrm{ECU}$ and the dispute is taken before the three other receivers of the same color as the defendant. These receivers learn the facts of the transaction and then vote anonymously on whether to require the "cheating" receiver to fulfill the contract. If a majority vote in favor of the plaintiff, the defendant must pay the plaintiff the outstanding balance plus the cost of dispute (2 ECU) incurred by the plaintiff. If a majority vote in favor of the defendant, the original transaction stands and the dispute cost incurred by the sender is sunk.

In theory, voting receivers are indifferent between voting in favor of the plaintiff and the defendant, as neither outcome affects their payoffs. However, if voters are concerned about their group's reputation and its impact on their future gains from exchange (which depend wholly on how much senders are willing to send to them), then they may be inclined to vote in favor of the plaintiff. On the other hand, if they also intend to not repay future promises in full, then they may vote in favor of other receivers of their color in hopes that those receivers 
will do the same for them when they are a defendant. Note that the jury institution also induces part of the information effect of the Info treatments, since the parties to any case that goes to a vote will receive information about the decisions of others that they would not receive in the baseline treatment. Our fourth treatment, the Jury - Info treatment, identifies the joint effects of information sharing and in-group punishment directly by combining the within-group information sharing of the Info treatments with the Jury mechanism. Here the group information table also includes details of any appeals to the jury.

Finally, as a robustness check on our Jury - Info treatment, we also run a treatment in which receivers choose whether or not to participate in each vote. Specifically, before receiving any information about the details of the transaction, receivers must choose whether to opt in at a cost of 2 ECU per case. This increases the cost of managing group reputation. We call this the Jury - Info - Pay treatment. Detailed instructions for each treatment and some sample screenshots are in Appendix B.

We recruited subjects randomly from the student body of a mid-sized university in the United States. A total of 272 subjects participated in our experiments, 16 per session. We ran 3 sessions of each treatment except for the Jury - Info treatment, for which we ran 5. Subjects entered the lab and were randomly assigned to visually isolated computer terminals at which they privately read the instructions. At the conclusion of the session subjects were paid their earnings in cash plus a $\$ 7$ show-up payment for arriving to the session on time. Average earnings were $\$ 16.25$ for a 60 minute session (not including the show-up payment).

\section{Results}

\subsection{Summary Statistics and Basic Results}

For most of the analysis, we focus on the 4 main treatments: No Jury - No Info, No Jury

- Info, Jury - No Info, and Jury - Info. As a robustness check, we will compare these 
treatments to the one where receivers paid to vote in the jury (Jury - Info - Pay) in Section 3.4 .

Table 1 reports summary statistics for all treatments. There are numerous treatment effects that stand out through a simple analysis of the means. First, note that the mean amount sent is lower in the baseline treatment (No Jury - No Info) than in the other three treatments. This can also be seen in figure 1, which plots histograms of the amount sent by senders in each treatment. The differences in amount sent are important, because total 


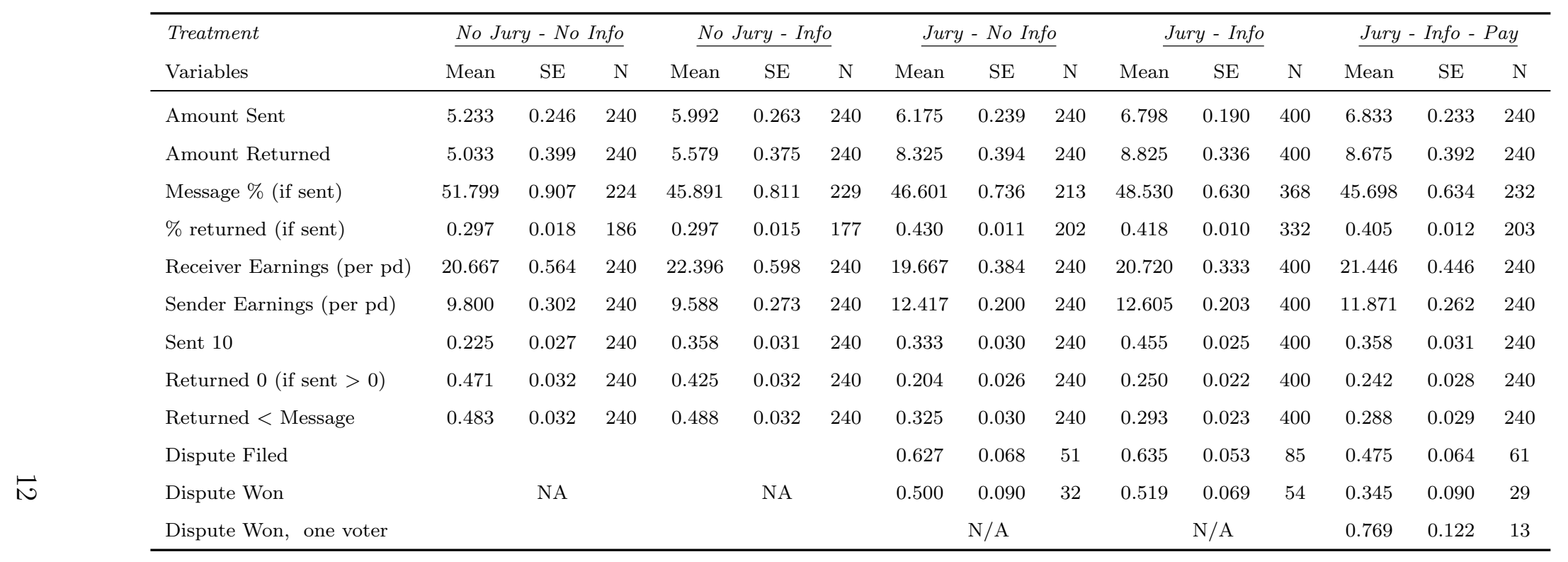

Table 1: Summary Statistics 
welfare is almost solely dependent on the amount sent. ${ }^{6}$ Total welfare increases threefold for every ECU sent, whereas every ECU returned is merely a transfer from one player to another.
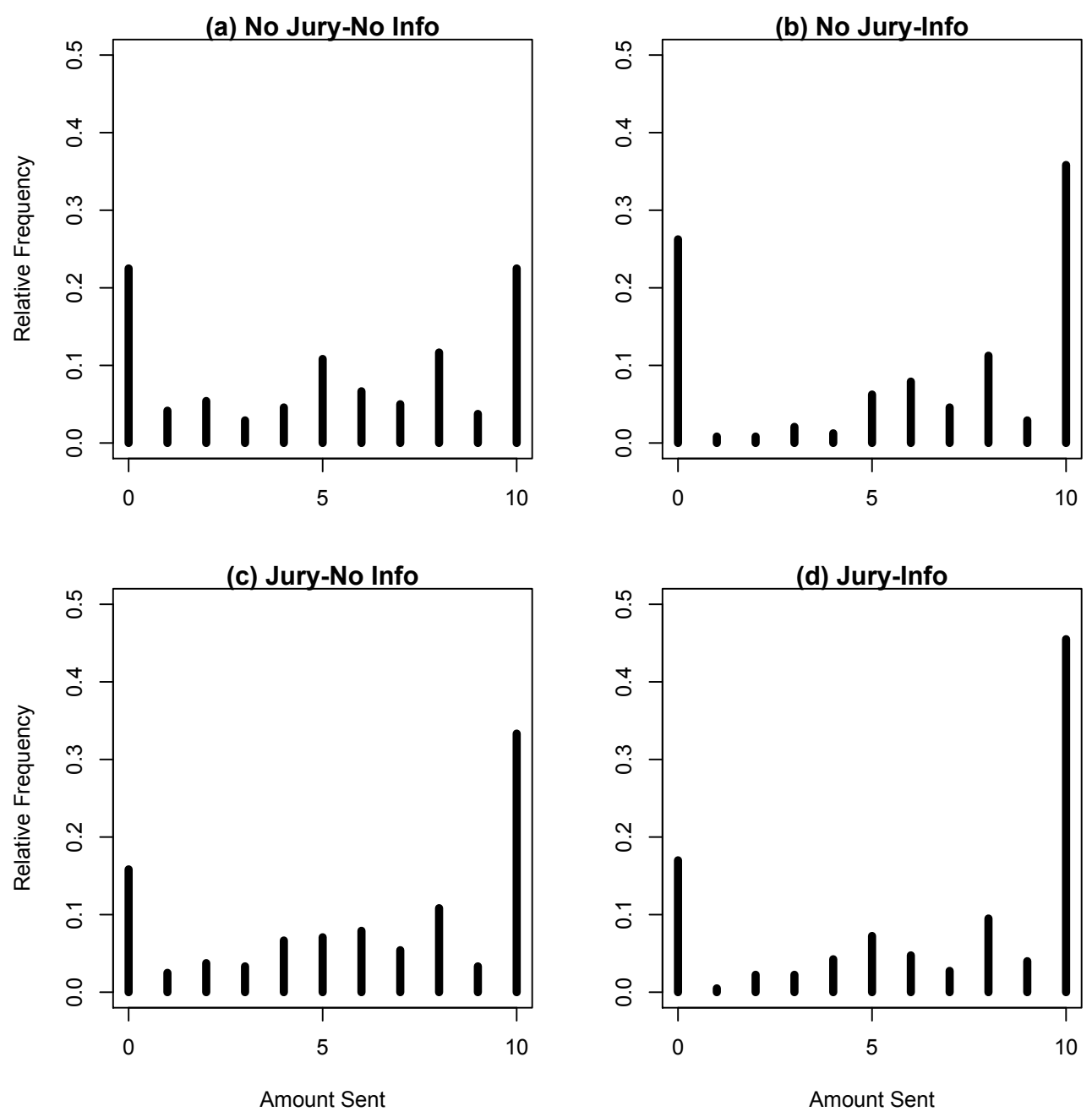

Figure 1: Histograms of Amount Sent by Treatment. Each panel displays a histogram of amounts sent by $\mathrm{S}$ for one treatment.

Returning to table 1, there also appear to be treatment differences in the amount returned by receivers. The relevant difference here, however, is between the Jury and No Jury treatments. This suggests that while both the availability of information about others in

\footnotetext{
${ }^{6}$ In the Jury treatments, total welfare is also a function of whether a trial occurs, since a trial reduces total welfare by 2 ECU.
} 
one's group and the jury mechanism are working to increase the amount sent, they work in different ways.

Of course, comparing means can only tell us so much. In order to understand the determinants of the amount sent and returned, we must control for other variables which may affect the decision in question. For example, the amount sent is likely a function of the message received (as well as whether a message was sent), and the amount returned is almost certainly a function of the amount sent. To this end, Table 2 reports the results of linear regressions explaining messages sent by Receivers, amounts sent by Senders and percent returned by Receivers. In each regression, we include nested random effects at the session and subject-in-session levels to control for repeated measures.

We first seek the determinants of the message sent. Since this is the first action taken in each period, it affects all subsequent actions taken (i.e., amount sent and received, the jury outcomes). Column 1 reports the results of are regression where the dependent variable is the message sent (in percentage terms) and the independent variables are treatment dummies (No Jury - Info, Jury - No Info, and Jury - Info $)^{7}$, a period trend, and a constant. Column 2 includes a variable which averages the message that the receiver sent in all previous periods in order to control for individual idiosyncrasies. ${ }^{8}$ We find that relative to the Baseline $\left(N_{o}\right.$ Jury - No Info), both the No Jury - Info and the Jury - No Info treatments significantly reduce the percent offered in the pre-play message, but there is no difference in the Jury Info treatment. It is possible that these results arise because, in the absence of a mechanism such as information or a jury to encourage compliance, receivers in the No Jury - No Info treatment have to promise more in order to encourage senders to send tokens. Nevertheless, as we show next, the amount sent is significantly smaller in the No Jury - No Info treatment

\footnotetext{
${ }^{7}$ We use treatment dummies instead of jury and info dummies because while the No Jury-Info and JuryInfo treatments both include the group information table, the information conditions are not technically identical, since the jury provides additional information.

${ }^{8}$ In order to incorporate this variable, we dropped period one observations. We cannot add individual fixed effects, since each individual was assigned to only one treatment.
} 


\begin{tabular}{|c|c|c|c|c|c|c|}
\hline \multirow{3}{*}{$\begin{array}{l}\text { Action taken by: } \\
\text { Dependent Variable: } \\
\text { No Jury-Info }\end{array}$} & \multirow{2}{*}{\multicolumn{2}{|c|}{$\begin{array}{l}(1) \quad(2) \\
\text { Receiver } \\
\text { Message \% }\end{array}$}} & $(3)$ & (4) & $(5)$ & (6) \\
\hline & & & \multicolumn{2}{|c|}{$\begin{array}{l}\text { Sender } \\
\text { Amount Sent }\end{array}$} & \multicolumn{2}{|c|}{$\begin{array}{c}\text { Receiver } \\
\text { Returned \% - Message \% }\end{array}$} \\
\hline & $\begin{array}{r}-0.058^{*} \\
(0.031)\end{array}$ & $\begin{array}{r}-0.043^{*} \\
(0.024)\end{array}$ & $\begin{array}{l}1.307^{*} \\
(0.724)\end{array}$ & $\begin{array}{l}1.126^{*} \\
(0.674)\end{array}$ & $\begin{array}{c}0.023 \\
(0.065)\end{array}$ & $\begin{array}{l}-0.000 \\
(0.034)\end{array}$ \\
\hline Jury-No Info & $\begin{array}{c}-0.062^{* *} \\
(0.031)\end{array}$ & $\begin{array}{c}-0.053^{* *} \\
(0.025)\end{array}$ & $\begin{array}{c}1.952^{* * *} \\
(0.724)\end{array}$ & $\begin{array}{c}2.042^{* * *} \\
(0.674)\end{array}$ & $\begin{array}{c}0.190^{* * *} \\
(0.064)\end{array}$ & $\begin{array}{c}0.109^{* * *} \\
(0.035)\end{array}$ \\
\hline Jury-Info & $\begin{array}{l}-0.041 \\
(0.028)\end{array}$ & $\begin{array}{l}-0.035 \\
(0.022)\end{array}$ & $\begin{array}{c}2.192^{* * *} \\
(0.646)\end{array}$ & $\begin{array}{c}2.039^{* * *} \\
(0.602)\end{array}$ & $\begin{array}{c}0.130^{* *} \\
(0.058)\end{array}$ & $\begin{array}{c}0.086^{* * *} \\
(0.031)\end{array}$ \\
\hline $\begin{array}{l}\text { Inverse Period } \\
\left(\frac{1}{t}\right)\end{array}$ & $\begin{array}{c}-0.119^{* * *} \\
(0.025)\end{array}$ & $\begin{array}{c}-0.062^{* *} \\
(0.026)\end{array}$ & $\begin{array}{c}3.056^{* * *} \\
(0.815)\end{array}$ & $\begin{array}{c}2.437^{* * *} \\
(0.832)\end{array}$ & $\begin{array}{l}-0.002 \\
(0.033)\end{array}$ & $\begin{array}{l}-0.034 \\
(0.035)\end{array}$ \\
\hline $\begin{array}{l}\text { Avg. Message Pvs. } \\
\left(\frac{\sum_{t=1}^{t-1} \% \text { message }}{t-1}\right)\end{array}$ & & $\begin{array}{c}0.276^{* * *} \\
(0.035)\end{array}$ & & & & \\
\hline $\begin{array}{l}\text { Message } * \text { Message Sent } \\
(\text { message } \% * \text { message dummy) }\end{array}$ & & & $\begin{array}{c}10.205^{* * *} \\
(0.928)\end{array}$ & $\begin{array}{c}10.398^{* * *} \\
(0.933)\end{array}$ & & \\
\hline $\begin{array}{l}\text { No Message } \\
\text { (no message dummy) }\end{array}$ & & & $\begin{array}{c}0.803 \\
(0.602)\end{array}$ & $\begin{array}{l}0.887 \\
(0.605)\end{array}$ & & \\
\hline $\begin{array}{l}\text { Avg. Sent Pvs. } \\
\left(\frac{\sum_{t=1}^{t-1} \text { sent }}{t-1}\right)\end{array}$ & & & & $\begin{array}{c}0.355^{* * *} \\
(0.058)\end{array}$ & & \\
\hline $\begin{array}{l}\text { Sent } \\
\text { (amt. sent by S) }\end{array}$ & & & & & $\begin{array}{c}0.001 \\
(0.002)\end{array}$ & $\begin{array}{c}0.001 \\
(0.002)\end{array}$ \\
\hline $\begin{array}{l}\text { Avg. Returned }- \text { Message Pvs. } \\
\left(\frac{\sum_{t=1}^{t-1} \% \text { returned-\%message }}{t-1}\right)\end{array}$ & & & & & & $\begin{array}{c}0.546^{* * *} \\
(0.045)\end{array}$ \\
\hline Constant & $\begin{array}{c}0.549^{* * *} \\
(0.023)\end{array}$ & $\begin{array}{c}0.405^{* * *} \\
(0.026)\end{array}$ & $\begin{array}{l}-0.732 \\
(0.738)\end{array}$ & $\begin{array}{c}-2.882^{* * *} \\
(0.804)\end{array}$ & $\begin{array}{c}-0.222^{* * *} \\
(0.048)\end{array}$ & $\begin{array}{c}-0.095^{* * *} \\
(0.030)\end{array}$ \\
\hline \multicolumn{7}{|l|}{ Wald Test $p$-values } \\
\hline No Jury-Info = Jury-No Info & 0.893 & 0.688 & 0.372 & 0.174 & $0.010^{* *}$ & $0.002^{* * *}$ \\
\hline No Jury-Info = Jury-Info & 0.532 & 0.705 & 0.171 & 0.128 & $0.065^{*}$ & $0.005^{* * *}$ \\
\hline Jury-No Info = Jury-Info & 0.440 & 0.410 & 0.710 & 0.997 & 0.296 & 0.450 \\
\hline $\begin{array}{l}\text { Observations } \\
\text { Log Likelihood }\end{array}$ & $\begin{array}{c}938 \\
814.3\end{array}$ & $\begin{array}{c}938 \\
834.9\end{array}$ & $\begin{array}{c}1008 \\
-2658.4\end{array}$ & $\begin{array}{c}1008 \\
-2646.2\end{array}$ & $\begin{array}{c}760 \\
438.8\end{array}$ & $\begin{array}{c}748 \\
470.9\end{array}$ \\
\hline
\end{tabular}

Table 2: Mixed Effects Regressions Explaining Sender and Receiver Decisions

than in all other treatments.

We analyze the determinants of the amount sent in columns 3 and 4, and we again include treatment dummies and a period trend. In these regressions, we control for the message amount (if there was a message) and include a separate dummy equaling one if no message was sent. Column 4 also includes a variable controlling for the average amount 
sent in previous periods. The results suggest that both information and access to the jury significantly increase the amount sent. Figure 1 indicated that much of the reason for observed treatment differences is that subjects in the No Jury - No Info treatment were far less likely to send their entire endowment than they were in the other 3 treatments (observed probabilities are 0.225 in the No Jury - No Info treatment vs. 0.358, 0.333, and 0.455 in the No Jury - Info, Jury - No Info, and Jury - Info treatments, respectively). We cannot reject hypotheses that these 3 treatment coefficients are equal (Wald test $p$-values are at the bottom of Table 2).

Finally, we analyze the receiver's decision of how much to return to the sender. It is clear from the summary statistics that the receiver returns significantly more than the Nash equilibrium prediction of 0 in all four treatments. Yet, just looking at the percent returned is slightly misleading - since we know that the message sent was not merely cheap talk, it is more informative to analyze the amount that the receiver returned relative to the amount he offered to return in the message. Figure 2 displays histograms of the relative returns on trust for each treatment, where the relative return is defined as $\left(\frac{\text { AmountReceived }}{\text { AmountOffered }}-1\right) * 100$. In all treatments the modal return is exactly the amount offered $(0 \%)$, but the probability of returning nothing is substantially higher in the two No Jury treatments. This result is confirmed in columns 5 and 6 of Table 2. In these columns, we regress the difference between percentage returned and percentage offered in the pre-play message on the treatment dummies, a period trend, the amount sent, and a constant. Column 6 also includes a control for the receiver's previous behavior. Positive and significant estimated coefficients on the two jury treatment dummy variables indicate that the presence of the jury institution increases the percent returned (relative to the message), but the No Jury - Info treatment is not statistically different from the No Jury - No Info baseline. Moreover, the coefficients on the two jury treatments are significantly greater than the coefficient on the No Jury - Info treatment.

Many important phenomena are apparent in these regression results. First, both in- 

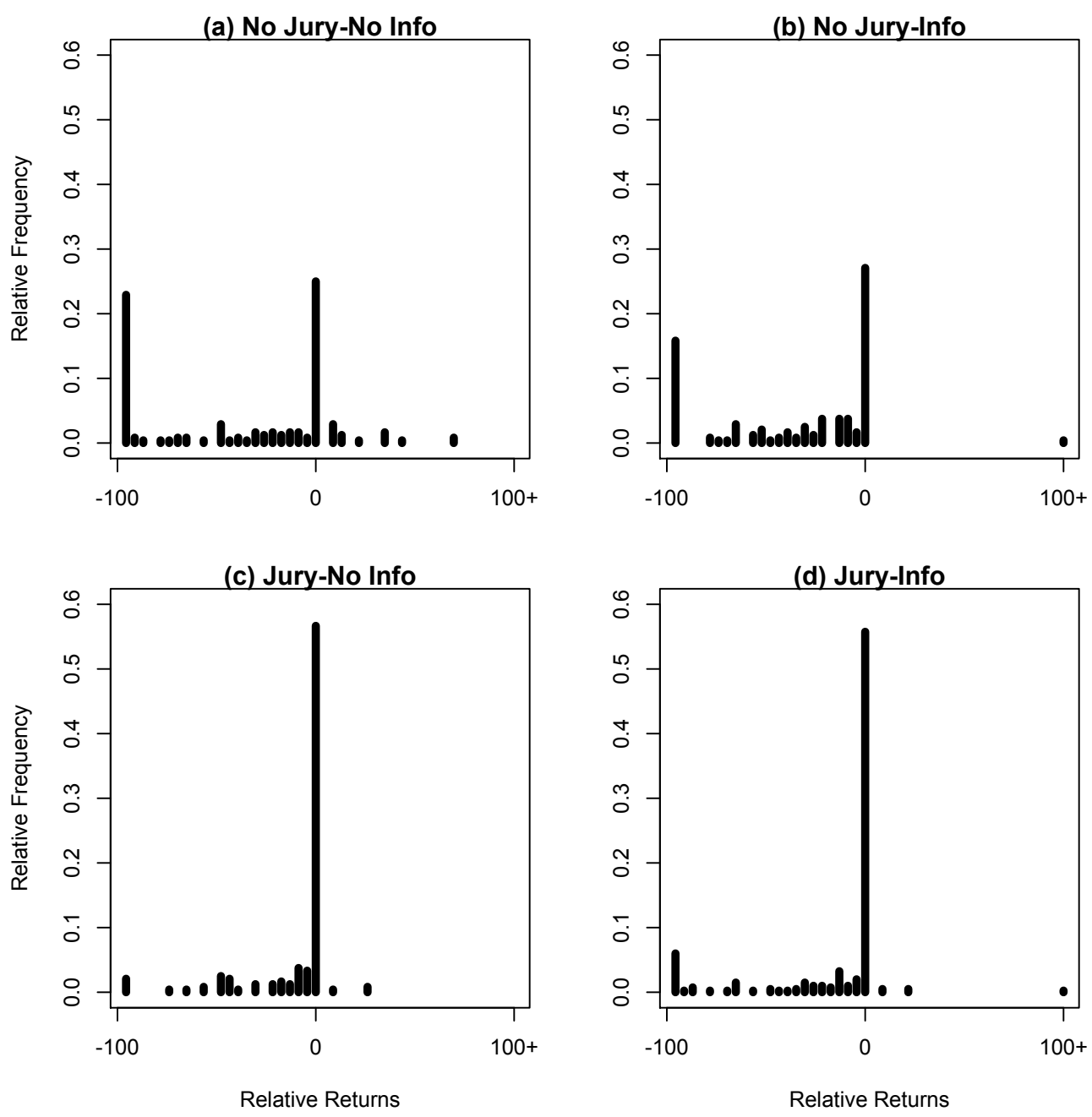

Figure 2: Histograms of Relative Returns by Treatment. Each panel displays a histogram of S's relative return on trust for one treatment. Relative returns are computed as $\frac{\text { AmountReturned }}{\text { Amountoffered }}-1$ and reported in percentage terms, so that $0 \%$ implies that S got exactly what was offered in pre-play communication, and $-100 \%$ indicates that $\mathrm{R}$ returned 0 ECU.

formation and the jury institution appear to encourage trust (measured in amount sent in columns). On the other hand, columns (5) and (6) indicate that the presence of in-group punishment from a jury is enough to encourage many receivers to fulfill their promises, but the indirect punishment that operates through group reputation was not. On the surface, these results are difficult to reconcile - if receivers were more likely to fulfill their promises in only the jury treatments, why did senders send more in both the jury and the group informa- 
tion treatments? To answer this question, we must dig deeper and identify the mechanisms through which information and juries work to facilitate trust. In particular, the regressions in Table 2 ignore the information available to players from previous periods of play. We should expect this information to play an important role in decision-making, and it may be the case that the role of past information varies in the different treatments. Senders that are "ripped off" in early periods may be reluctant to send anything to a receiver of that color in future periods. This possibility is magnified in the Information treatments - a sender may be reluctant to send anything in the future to a receiver of a color that ripped off any of the other three members of his group as well. Likewise, in the Jury treatments, a sender may avoid sending anything to receivers of a color that did not convict a fellow receiver for a previous transgression. In other words, the simple regressions presented in Table 2 do not account for the role that path dependence plays in the sending and returning decision. We address this concern in the next section.

\subsection{Controlling for Path Dependence}

In this section, we control for the effect of past actions on the send and return decisions. We start by analyzing how past actions affect the sender's decision.

\subsubsection{Amount Sent}

To highlight the importance of path dependence, recall Figure 1, which showed that there is a substantially higher probability of sending the whole endowment in all three Jury and Info treatments relative to the No Jury - No Info baseline. Figure 3 displays time series of the probability of sending the entire endowment and of sending nothing, by treatment. In early periods, both treatments that provide group Info exhibit higher probabilities of sending the whole endowment than their No Info counterparts. However, in both Jury treatments, the

probability of sending the whole endowment increases over time, while it is roughly flat or 
declining in the No Jury treatments. ${ }^{9}$ Similarly in both Jury treatments, the probability of sending nothing remains flat, while in both No Jury treatments, it is increasing over time.
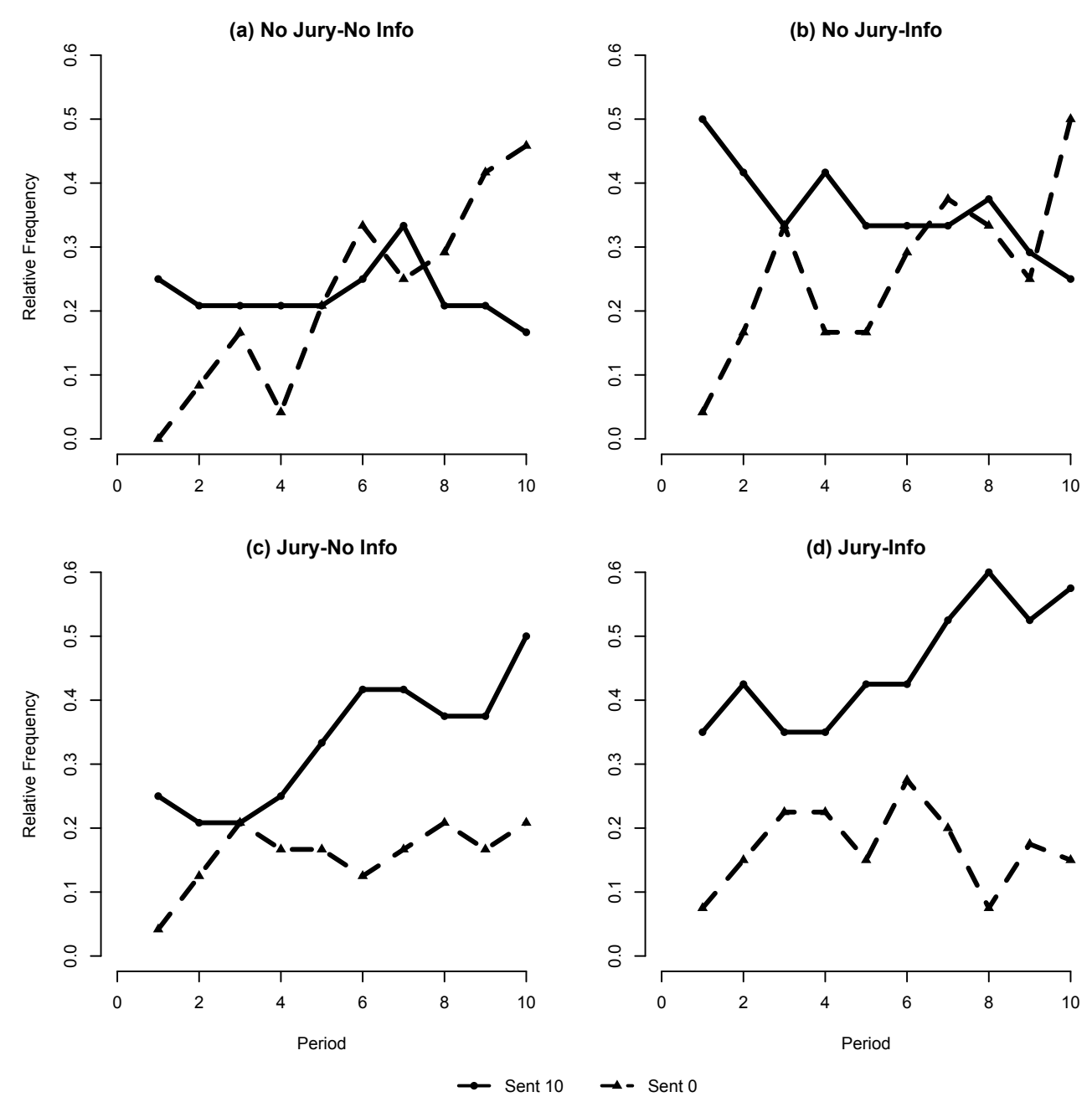

Figure 3: Time Series of the Probability of Sending both 10 and 0 Units by Treatment. Each panel displays time series of average observed probabilities for one treatment.

In Table 3, we analyze mixed-effects linear regressions where the dependent variable is the amount sent by S. As before we include nested random effects for each subject-in-session to control for repeated measures. These regressions are structured similarly to those in Column 4 of Table 2, but with the inclusion of variables encoding various past actions that may affect

\footnotetext{
${ }^{9}$ The evidence from the No Jury treatments is consistent with evidence that group reputation can encourage early-period cooperation in experimental labor markets (Healy, 2007).
} 


\begin{tabular}{|c|c|c|c|}
\hline & $(1)$ & $(2)$ & (3) \\
\hline $\begin{array}{l}\text { Action taken by: } \\
\text { Dependent Variable: }\end{array}$ & \multicolumn{3}{|c|}{$\begin{array}{c}\text { Sender } \\
\text { Amount Sent }\end{array}$} \\
\hline No Jury-Info & $\begin{array}{l}1.030^{*} \\
(0.563)\end{array}$ & $\begin{array}{l}1.043^{*} \\
(0.580)\end{array}$ & $\begin{array}{l}1.641^{* *} \\
(0.650)\end{array}$ \\
\hline Jury-No Info & $\begin{array}{r}1.436^{* *} \\
(0.575)\end{array}$ & $\begin{array}{c}1.627^{* * *} \\
(0.600)\end{array}$ & $\begin{array}{l}1.561^{* *} \\
(0.608)\end{array}$ \\
\hline Jury-Info & $\begin{array}{c}1.439^{* * *} \\
(0.517)\end{array}$ & $\begin{array}{c}1.634^{* * *} \\
(0.539)\end{array}$ & $\begin{array}{c}2.590^{* * *} \\
(0.572)\end{array}$ \\
\hline $\begin{array}{l}\text { Inverse Period } \\
\left(\frac{1}{t}\right)\end{array}$ & $\begin{array}{c}1.321 \\
(0.864)\end{array}$ & $\begin{array}{l}1.578^{*} \\
(0.841)\end{array}$ & $\begin{array}{c}0.822 \\
(0.839)\end{array}$ \\
\hline $\begin{array}{l}\text { Message } * \text { Message Sent } \\
(\text { message } \% * \text { message dummy) }\end{array}$ & $\begin{array}{c}10.118^{* * *} \\
(0.914)\end{array}$ & $\begin{array}{c}10.219^{* * *} \\
(0.919)\end{array}$ & $\begin{array}{c}10.738^{* * *} \\
(0.905)\end{array}$ \\
\hline $\begin{array}{l}\text { No Message } \\
\text { (no message dummy) }\end{array}$ & $\begin{array}{c}0.750 \\
(0.594)\end{array}$ & $\begin{array}{c}0.777 \\
(0.597)\end{array}$ & $\begin{array}{c}0.959 \\
(0.585)\end{array}$ \\
\hline $\begin{array}{l}\text { Avg. Sent Pvs. } \\
\left(\frac{\sum_{t=1}^{t-1} \text { sent }}{t-1}\right)\end{array}$ & $\begin{array}{c}0.391^{* * *} \\
(0.057)\end{array}$ & $\begin{array}{c}0.390^{* * *} \\
(0.057)\end{array}$ & $\begin{array}{c}0.390^{* * *} \\
(0.056)\end{array}$ \\
\hline $\begin{array}{l}\text { Pvs. Ripoff, Same } \\
\text { (fraction of pvs. pds. S ripped off by R's group) }\end{array}$ & $\begin{array}{l}-2.101^{* * *} \\
(0.333)\end{array}$ & $\begin{array}{l}-1.882^{* * *} \\
(0.352)\end{array}$ & $\begin{array}{c}-1.884^{* * *} \\
(0.346)\end{array}$ \\
\hline $\begin{array}{l}\text { Pvs. Ripoff, Other } \\
\text { (fraction of pvs. pds. S ripped off by other (not R's) group) }\end{array}$ & $\begin{array}{l}-0.490 \\
(0.365)\end{array}$ & & \\
\hline $\begin{array}{l}\text { Pvs. Win * Jury } \\
\text { (\# of pvs. trials won by S vs. R's group * jury dummy) }\end{array}$ & & $\begin{array}{l}-0.018 \\
(0.375)\end{array}$ & $\begin{array}{c}0.403 \\
(0.373)\end{array}$ \\
\hline $\begin{array}{l}\text { Pvs. Lose }{ }^{*} \text { Jury } \\
\text { (\# of pvs. trials lost by S vs. R's group * jury dummy) }\end{array}$ & & $\begin{array}{l}-0.233 \\
(0.310)\end{array}$ & $\begin{array}{l}-0.142 \\
(0.308)\end{array}$ \\
\hline $\begin{array}{l}\text { Pvs. Ripoff of Group * Info } \\
\text { (fraction of pvs. times others in S's group ripped of by R's group * info) }\end{array}$ & & & $\begin{array}{c}-1.312^{* *} \\
(0.625)\end{array}$ \\
\hline $\begin{array}{l}\text { Pvs. Wins of Group } * \text { Jury } * \text { Info } \\
(\# \text { of pvs. trials won by others in S's group vs. R's group * jury * info) }\end{array}$ & & & $\begin{array}{l}-0.207 \\
(0.257)\end{array}$ \\
\hline $\begin{array}{l}\text { Pvs. Losses of Group } * \text { Jury }{ }^{*} \text { Info } \\
(\# \text { of pvs. trials lost by others in S's group vs. R's group } * \text { jury } * \text { info) }\end{array}$ & & & $\begin{array}{c}-1.142^{* * *} \\
(0.234)\end{array}$ \\
\hline Constant & $\begin{array}{c}-1.607^{* *} \\
(0.791)\end{array}$ & $\begin{array}{c}-1.997^{* * *} \\
(0.775)\end{array}$ & $\begin{array}{c}-2.104^{* * *} \\
(0.769)\end{array}$ \\
\hline \multicolumn{4}{|l|}{ Wald Test $p$-values } \\
\hline No Jury-Info = Jury-No Info & 0.477 & 0.327 & 0.904 \\
\hline No Jury-Info = Jury-Info & 0.425 & 0.269 & 0.107 \\
\hline Jury-No Info = Jury-Info & 0.995 & 0.990 & $0.063^{*}$ \\
\hline Observations & 1008 & 1008 & 1008 \\
\hline Log Likelihood & -2626.9 & -2627.5 & -2605.3 \\
\hline
\end{tabular}

Table 3: Mixed Effects Regressions Explaining the Amount Sent by Treatment 
the sender's action in the present. In Column 1 of Table 3, we include two variables that help control for the sender's history (as opposed to the history of those in his group): the fraction of previous periods he has been ripped off by a receiver in the group with which he is currently matched, and the fraction of previous periods he has been ripped off by a receiver in the group with which he is not currently matched. If group reputation plays a salient role in the decision to send, then the coefficient on the former but not the latter should be significant. That is, we expect a group reputation-sensitive player that has been ripped off by a blue receiver to be wary of sending to blues in the future but not to reds. We include the latter variable because it is possible that being ripped off in the past by anyone, regardless of group, will make a sender wary of trusting a receiver in the future, regardless of group identity. But this is not what we find. ${ }^{10}$ Instead, we find that being ripped off by a receiver of the same color as the sender is currently matched with significantly decreases the amount sent (in both an economic and statistical sense), whereas being ripped off by a receiver in the other group has no statistically significant effect (we thus drop the latter variable in future regressions). The rest of the coefficients are similar to those found in Table 2, although the period trend is no longer statistically significant. Thus, without controlling for past actions (as in Table 2), it may appear that there is a trend over time that is unrelated to the history of interactions, but these results suggest that this trend is actually a result of path dependence inherent in a multi-period game.

After controlling for the sender's previous interactions with receivers in column 1 , it is still apparent that both the presence of a jury institution and group information encourage senders to be more trusting than in the No Jury - No Info treatment. Yet, this regression tells us little about the mechanisms that are specific to the inclusion of information or a jury.

\footnotetext{
${ }^{10}$ The coefficient on the "previous ripoff, other" variable enters as statistically significant if it is included in the regression reported in column 3, where we break down information-specific and jury-specific past actions in various components. The primary results do not change however; the Jury - Info coefficient is still significantly greater than the Jury - No Info coefficient $(\mathrm{p}=0.05)$ and is marginally greater than the No Jury - Info coefficient $(\mathrm{p}=0.15)$. These results are available upon request.
} 
After all, one has information on his own past interactions in all four treatments. To address the treatment-specific information, columns 2 and 3 include controls for past actions that may influence the amount sent in one or both of the Jury and Info treatments but not the No Jury - No Info baseline. Column 2 controls for past actions of the jury that are only relevant for the Jury treatments (and these variables are thus interacted with a dummy equaling one if the treatment contains a jury option). In theory, if group reputation is sustained by the jury, one would suspect that it matters how past juries actually voted. If in previous periods, the sender has lost trials against other members of the receiver's group, then the sender may reasonably expect that he will lose a trial if he takes a transgressing receiver to court. The converse is true if the jury frequently convicted in the past. Yet, we find that the past voting decisions of the jury had no statistically significant effect on sending behavior. The mere presence of a jury is still statistically and economically significant (the coefficients on the two jury treatment dummies are highly significant), but the actual past actions of the jury appear to have no effect on behavior. In part, this is because ripoffs are relatively rare in the Jury treatments - occurring in roughly $30 \%$ of cases vs. nearly $50 \%$ in the other two treatments. As we will highlight in the next section, the threat of going to trial is sufficient to induce good behavior on the part of receivers, which spills over into the amount sent.

In column 3, we control for previous actions which may affect decisions in the information treatments. The first variable we control for is the fraction of times others in the sender's group have been ripped off by a receiver in the group with which the sender is currently matched. Senders only have this information in the information treatments, and it is therefore interacted with an Info dummy. The other two variables are ones that are only relevant in the presence of both the jury institution and information (i.e., the Jury - Info treatment). These are, namely, the total number of trials won and lost by other senders in one's group against receivers from the group with which the sender is currently matched. The coefficients on the previous ripoffs of others in the sender's group as well as the previous trials lost by 
others in the group both have a strong and statistically significant negative effect on the amount sent. Perhaps more importantly, after controlling for information-specific variables, it appears that there is a (marginally) statistically significant difference in the amount sent when both the jury and information are present (i.e., the Jury - Info treatment) and every other treatment. We can reject the null that the Jury - Info coefficient equals the No Jury - Info and the Jury - No Info at $\mathrm{p}=0.107$ and 0.063 . This means that the jury institution and information are complements; as long as receivers act to uphold group reputation by convicting their fellow transgressors, the presence of the jury and information encourages greater trade than either the jury or information do individually.

Result 1: After controlling for previous actions, the amount sent is lower in the No Jury - No Info treatment than in all other treatments.

Result 2: After controlling for previous actions, the amount sent is greater when both the jury and information are present than when one but not both are present.

These results shed significant light on the mechanisms generating welfare gains in the information and jury treatments. First, it suggests that past actions are extremely important in the information treatments. If members of one's group are always ripped off by the receiver's group (i.e., the variable previous ripoff of group equals 1), practically all of the increased welfare made available by the presence of information disappears (a Wald test cannot reject the null hypothesis that the estimated coefficients on the No Info - Jury dummy variable and the Previous Ripoffs of Group*Info sum to 0, $p$-value $=0.63$ ).

This allows us to explain the treatment differences in time trends noted in Figure 3. Figure 4 displays time series of the probability that a receiver rips off a sender by treatment and reveals a clear difference between the Jury and No-Jury treatments. When the jury is available, individuals and groups are much less likely to have been ripped off in the past, and thus, the Pvs Ripoff variables take different values across treatments. This explains a large 
part of the temporal decline in amount sent in the No Jury treatments, and it highlights the complementarity of the two mechanisms, for which we find further support in the interaction of the Jury-Info and Previous Convictions variables.

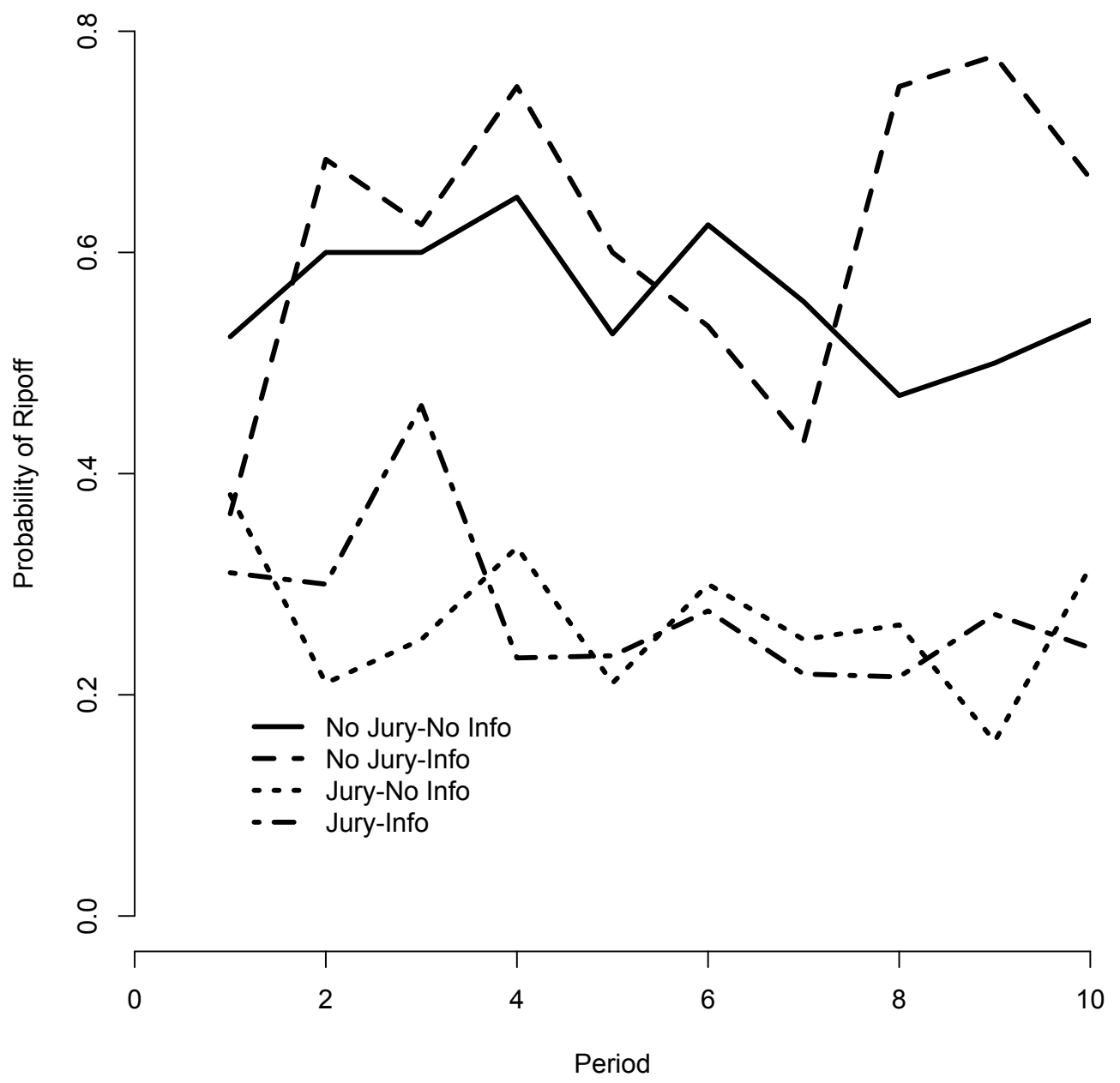

Figure 4: Time Series of the Probability that a Receiver Returned Less than Promised by Treatment. Each line displays a time series of average observed probability for one treatment.

Combined, these results help resolve the contradiction pointed out at the end of the last subsection. There, we noted that although senders sent more in all of the Jury and Info treatments, receivers only returned more in the presence of a jury. Given this, why would senders be willing to send more in the No Jury - Info treatment? The answer lies in large 
part in the fact that the results in Table 2 did not account for past actions. In the information treatments, senders have four times as much information as in the No Jury - No Info treatment. When receivers have previously resisted the temptation to rip off senders in the group in question, senders are more trusting; the opposite is true when receivers have repeatedly ripped senders off. Hence, while receivers may not return more relative to the message on average in the information treatments, when they do fulfill their promises, it encourages senders to send more (relative to no-information treatments). In this sense, making group information available accentuates path dependence. Groups in the Info treatments with a "good" history maintain higher levels of trust, and groups with a "bad" history, exhibit sharper declines.

Result 3: There are greater welfare gains in the two information treatments than the No Jury - No Info baseline because subjects actually use the information; welfare is reduced if receivers treated a sender's group members poorly in the past.

Result 4: There are greater welfare gains in the jury treatments than the No Jury No Info baseline because of the mere existence of the jury. Past decisions by juries do not significantly impact the amount sent in the absence of information-sharing, but senders do take into account how juries treated their group members when the jury is combined with information-sharing.

Once more, the history of actions taken in the jury treatments only impacts the amount sent when combined with information sharing (as evidenced by the negative and significant coefficient on our variable measuring previous trials lost by the group). This suggests that the jury institution encourages trust through a different mechanism than the one that works via information sharing. When the jury is available, the fact that a cheating receiver can be directly punished is sufficient to encourage greater trust. The most likely explanation for this result is that the presence of the jury reduces the incentive of the receiver to take 
actions that could send them to trial. We test whether this is the case in the next section, which analyzes the actions taken by receivers.

\subsubsection{Amount Returned}

The results reported in Table 2 indicated that the addition of the jury but not of informationsharing positively affects the amount returned relative to the amount promised in the message. In this section, we break this result down further to control for the potential presence of path dependence.

Table 4 reports the results of mixed effects linear regressions explaining the difference between the percent returned and the percent offered in the pre-play message. These regressions are structured similarly to the one reported in Column 6 of Table 2, but with the addition of variables which control for past actions. Column 1 of Table 4 includes a variable that measures the the average difference in percent returned and percent offered pre-play in all previous periods. This variable is highly significant. The simple fraction of ripoffs is not statistically significant. The other coefficients are very similar to those found in Column 6 of Table 2 .

In Column 2 of Table 4, we include two variables that control for personal experience in the jury treatments: the number of times the receiver has been convicted and acquitted in the past. Here, we find that the actions taken by previous juries have an important effect on the amount returned. If the receiver has been convicted in the past, she is likely to return more (relative to the amount promised) in the future. Although this is not surprising, we do note that this effect only accounts for a small fraction of the effect that the presence of a jury has on the receiver's behavior; the coefficients on the Jury - No Info and Jury Info dummies decrease only slightly and remain highly significant. This suggests that some feature of the jury mechanism affects the behavior of receivers beyond the impact of how it has been employed in the past. Receivers adjust their behavior in anticipation of punishment 
for cheating.

Finally, in Column 3 of Table 4, we include three variables that may be affected by information: the fraction of previous periods that others in the receiver's group ripped off a sender in the group with which the receiver is currently matched, and the number of previous trials in which other group members were either convicted or acquitted. If group reputation is a salient motivation in receiver's actions, we would expect these coefficients to be statistically significant. However, this is not what we find. Not only are none of these coefficients statistically significant, but the coefficients of all other variables are nearly identical to those reported in Column 2.

The interpretation of these results is straight-forward. Information-sharing has no direct effect on receiver's decisions, while the jury institution increases the amount sent relative to the message. It does so in two ways. First, receivers who are in groups that have convicted in the past return more in the future. Second, the mere presence of the jury institution increases the amount returned, regardless of past votes; the threat of punishment is sufficient to induce additional cooperation.

Result 5: Receivers return significantly more relative to the message when juries are present than when they are not, but the presence of information-sharing does not affect their behavior relative to the No Jury - No Info baseline.

Result 6: Receivers who were previously convicted return significantly more relative to the message in the jury treatments, but information about other receivers in their group does not affect their behavior relative to the No Jury - No Info baseline.

\subsubsection{Discussion}

Combining these results with those reported in the previous section, we see that juries and information work in different ways to facilitate welfare gains. The jury institution operates 


\begin{tabular}{|c|c|c|c|}
\hline \multirow{2}{*}{$\begin{array}{l}\text { Action taken by: } \\
\text { Dependent Variable: } \\
\text { No Jury-Info }\end{array}$} & \multicolumn{3}{|c|}{$\begin{array}{c}\text { Receiver } \\
\text { Returned \% - Message \% }\end{array}$} \\
\hline & $\begin{array}{l}-0.000 \\
(0.034)\end{array}$ & $\begin{array}{l}-0.000 \\
(0.033)\end{array}$ & $\begin{array}{c}0.013 \\
(0.037)\end{array}$ \\
\hline Jury-No Info & $\begin{array}{c}0.108^{* * *} \\
(0.035)\end{array}$ & $\begin{array}{c}0.093^{* * *} \\
(0.034)\end{array}$ & $\begin{array}{c}0.093^{* * *} \\
(0.034)\end{array}$ \\
\hline Jury-Info & $\begin{array}{c}0.085^{* * *} \\
(0.031)\end{array}$ & $\begin{array}{c}0.071^{* *} \\
(0.031)\end{array}$ & $\begin{array}{l}0.081^{* *} \\
(0.032)\end{array}$ \\
\hline $\begin{array}{l}\text { Inverse Period } \\
\left(\frac{1}{t}\right)\end{array}$ & $\begin{array}{l}-0.036 \\
(0.036)\end{array}$ & $\begin{array}{l}-0.018 \\
(0.036)\end{array}$ & $\begin{array}{l}-0.025 \\
(0.038)\end{array}$ \\
\hline $\begin{array}{l}\text { Sent } \\
\text { (amt. sent by } \mathrm{S})\end{array}$ & $\begin{array}{c}0.001 \\
(0.002)\end{array}$ & $\begin{array}{c}0.001 \\
(0.002)\end{array}$ & $\begin{array}{c}0.000 \\
(0.002)\end{array}$ \\
\hline $\begin{array}{l}\text { Avg. Returned - Message Pvs. } \\
\left(\frac{\sum_{t=1}^{t-1} \% \text { returned }-\% \text { message }}{t-1}\right)\end{array}$ & $\begin{array}{c}0.541^{* * *} \\
(0.048)\end{array}$ & $\begin{array}{l}0.531^{* * *} \\
(0.048)\end{array}$ & $\begin{array}{c}0.527^{* * *} \\
(0.049)\end{array}$ \\
\hline $\begin{array}{l}\text { Pvs. Ripoff } \\
\text { (fraction of pvs. pds. R ripped off one in S's group) }\end{array}$ & $\begin{array}{l}-0.007 \\
(0.017)\end{array}$ & $\begin{array}{l}-0.024 \\
(0.018)\end{array}$ & $\begin{array}{l}-0.027 \\
(0.018)\end{array}$ \\
\hline $\begin{array}{l}\text { Pvs. Conviction } * \text { Jury } \\
(\# \text { of pvs. trials convicted } * \text { jury })\end{array}$ & & $\begin{array}{c}0.050^{* * *} \\
(0.016)\end{array}$ & $\begin{array}{c}0.049^{* * *} \\
(0.016)\end{array}$ \\
\hline $\begin{array}{l}\text { Pvs. Acquittal } * \text { Jury } \\
(\# \text { of pvs. trials acquitted } * \text { jury })\end{array}$ & & $\begin{array}{c}0.013 \\
(0.019)\end{array}$ & $\begin{array}{l}0.015 \\
(0.019)\end{array}$ \\
\hline $\begin{array}{l}\text { Pvs. Ripoff of Group, Same * Info } \\
\text { (fraction of prior times others in R's group ripped off S's group * info) }\end{array}$ & & & $\begin{array}{l}-0.028 \\
(0.036)\end{array}$ \\
\hline $\begin{array}{l}\text { Pvs. Conviction, Group } * \text { Jury } * \text { Info } \\
(\# \text { of trials other members of R's group convicted } * \text { jury } * \text { info) }\end{array}$ & & & $\begin{array}{l}-0.002 \\
(0.014)\end{array}$ \\
\hline $\begin{array}{l}\text { Pvs. Acquittal, Group } * \text { Jury } * \text { Info } \\
\text { (\# of trials other members of R's group acquitted } * \text { jury } * \text { info) }\end{array}$ & & & $\begin{array}{l}-0.006 \\
(0.014)\end{array}$ \\
\hline Constant & $\begin{array}{c}-0.092^{* * *} \\
(0.031)\end{array}$ & $\begin{array}{c}-0.090^{* * *} \\
(0.030)\end{array}$ & $\begin{array}{c}-0.087^{* * *} \\
(0.030)\end{array}$ \\
\hline \multicolumn{4}{|l|}{ Wald Test $p$-values } \\
\hline No Jury-Info = Jury-No Info & $0.002^{* * *}$ & $0.006^{* * *}$ & $0.033^{* *}$ \\
\hline No Jury-Info = Jury-Info & $0.005^{* * *}$ & $0.019^{* *}$ & $0.044^{* *}$ \\
\hline Jury-No Info = Jury-Info & 0.449 & 0.470 & 0.707 \\
\hline $\begin{array}{l}\text { Observations } \\
\text { Log Likelihood }\end{array}$ & $\begin{array}{c}748 \\
471.0\end{array}$ & $\begin{array}{c}748 \\
476.2\end{array}$ & $\begin{array}{c}748 \\
476.7\end{array}$ \\
\hline \multicolumn{4}{|l|}{$\begin{array}{l}\text { Mixed effects results reported, with random effects on session and receiver. } \\
\text { Standard errors in parentheses. All regressions include a constant term. } \\
\text { Period } 1 \text { and observations where no message or } 0 \text { sent dropped from analysis. } \\
* * * \mathrm{p}<0.01,{ }^{* *} \mathrm{p}<0.05,{ }^{*} \mathrm{p}<0.1\end{array}$} \\
\hline
\end{tabular}

Table 4: Mixed Effects Regressions Explaining the Percent Returned - Percent Offered by Treatment

through its effect on receivers - they return more relative to the amount promised in jury treatments than they do in non-jury treatments. This encourages senders to send more, since they receive greater returns the more that they send. Information-sharing works through a 
different channel, namely through its effect on group reputation. Senders who are in groups that have been cheated in the past send much less than those who are in groups who have not been cheated in the past, and this is reinforced with information-sharing since individuals can also condition behavior on the experiences of others in their group. In other words, information accentuates path dependence - expanding trade when the group has a history of successful exchange and restraining it when the group has been exposed to cheating. The jury mechanism, on the other hand, simply reduces the likelihood of cheating, and when it is combined with information-sharing, this creates positive feedback facilitating further gains from exchange.

\subsection{When do subjects sue? When are cheaters convicted?}

Since the Jury clearly has a positive welfare impact, increasing both the amount sent and the amount returned, it is important to understand how subjects choose to employ it. To this end, Table 5 reports mixed effects linear probability estimates of the decision by the sender to employ the Jury mechanism. In a variety of specifications, we analyze the effects of information-sharing on the probability of a sender filing a dispute, and we find no evidence of statistically significant effects. Our results suggest that the likelihood of suing varies significantly only with the magnitude of the ripoff: the larger the difference between the amount promised and the amount received, the greater the probability of filing a dispute.

The fact that senders do not always file disputes in case of ripoffs could imply that some of the effect is due to path dependence - failure to convict in the past might make future filings seem futile. However, insignificant estimates of the effect of previous actions do not favor this interpretation. Instead it is likely that some of this effect is driven by the fact that not all ripoffs leave a sender worse off than he would have been in the absence of trade

- when we include a dummy variable that takes a value of 1 when the sender was ripped off but still received a payoff larger than his initial endowment, it is negative and significant. In 


\begin{tabular}{|c|c|c|c|c|}
\hline \multirow{2}{*}{$\begin{array}{l}\text { Action taken by: } \\
\text { Dependent Variable }\end{array}$} & \multicolumn{4}{|c|}{$\begin{array}{c}\text { Sender } \\
\text { Dispute }(0 / 1)\end{array}$} \\
\hline & $\begin{array}{l}-0.117 \\
(0.089)\end{array}$ & $\begin{array}{l}-0.128 \\
(0.089)\end{array}$ & $\begin{array}{c}-0.132 \\
(0.090)\end{array}$ & $\begin{array}{l}-0.093 \\
(0.105)\end{array}$ \\
\hline $\begin{array}{l}\text { Inverse Period } \\
\left(\frac{1}{t}\right)\end{array}$ & $\begin{array}{l}-0.006 \\
(0.134)\end{array}$ & $\begin{array}{l}-0.081 \\
(0.151)\end{array}$ & $\begin{array}{l}-0.087 \\
(0.153)\end{array}$ & $\begin{array}{l}-0.151 \\
(0.156)\end{array}$ \\
\hline $\begin{array}{l}\text { Sent } \\
\text { (amt. sent by S) }\end{array}$ & $\begin{array}{c}0.002 \\
(0.016)\end{array}$ & $\begin{array}{l}-0.000 \\
(0.016)\end{array}$ & $\begin{array}{l}-0.000 \\
(0.016)\end{array}$ & $\begin{array}{c}0.020 \\
(0.020)\end{array}$ \\
\hline $\begin{array}{l}\text { Ripoff Magnitude } \\
((\text { message } \% * \text { amt. received from } S)-\text { amt. returned by } \mathrm{R})\end{array}$ & $\begin{array}{c}0.043^{* * *} \\
(0.008)\end{array}$ & $\begin{array}{c}0.044^{* * *} \\
(0.008)\end{array}$ & $\begin{array}{c}0.045^{* * *} \\
(0.011)\end{array}$ & $\begin{array}{r}0.033^{* * *} \\
(0.008)\end{array}$ \\
\hline $\begin{array}{l}\text { Pvs. Ripoff } \\
\text { (fraction of pvs. pds. S ripped off by R's group) }\end{array}$ & & $\begin{array}{l}-0.131 \\
(0.124)\end{array}$ & $\begin{array}{l}-0.106 \\
(0.165)\end{array}$ & $\begin{array}{l}-0.052 \\
(0.166)\end{array}$ \\
\hline $\begin{array}{l}\text { Pvs. Win * Jury } \\
\text { (\# of pvs. trials won by S vs R's group * jury) }\end{array}$ & & & $\begin{array}{l}0.005 \\
(0.109)\end{array}$ & $\begin{array}{l}-0.006 \\
(0.108)\end{array}$ \\
\hline $\begin{array}{l}\text { Pvs. Lose * Jury } \\
\text { (\# of pvs. trials lost by S vs R's group * jury) }\end{array}$ & & & $\begin{array}{l}-0.024 \\
(0.066)\end{array}$ & $\begin{array}{l}-0.040 \\
(0.065)\end{array}$ \\
\hline $\begin{array}{l}\text { Pvs. Ripoff of Group * Info } \\
\text { (fraction of pvs. times others in S's group ripped off by R's group * info) }\end{array}$ & & & & $\begin{array}{l}0.029 \\
(0.225)\end{array}$ \\
\hline $\begin{array}{l}\text { Pvs. Wins of Group } * \text { Jury } * \text { Info } \\
\text { (\# of pvs. trials won by others in S's group vs. R's group } * \text { jury } * \text { info) }\end{array}$ & & & & $\begin{array}{c}0.009 \\
(0.077)\end{array}$ \\
\hline $\begin{array}{l}\text { Pvs. Losses of Group } * \text { Jury } * \text { Info } \\
(\# \text { of pvs. trials lost by others in S's group vs. R's group * jury * info) }\end{array}$ & & & & $\begin{array}{l}-0.104 \\
(0.071)\end{array}$ \\
\hline $\begin{array}{l}\text { Better than Autarky } * \text { Ripoff } \\
\text { (equals } \mathbf{1} \text { if } 10-\text { amt. sent }+ \text { amt. returned }>10 \text {, equals } \mathbf{0} \text { otherwise) }\end{array}$ & & & & $\begin{array}{r}-0.200^{*} \\
(0.106)\end{array}$ \\
\hline Constant & $\begin{array}{c}0.457^{* * *} \\
(0.144)\end{array}$ & $\begin{array}{c}0.532^{* * *} \\
(0.160)\end{array}$ & $\begin{array}{c}0.537^{* * *} \\
(0.163)\end{array}$ & $\begin{array}{r}0.569^{* * *} \\
(0.164)\end{array}$ \\
\hline $\begin{array}{l}\text { Observations } \\
\text { Log Likelihood }\end{array}$ & $\begin{array}{c}136 \\
-75.82\end{array}$ & $\begin{array}{c}136 \\
-75.26\end{array}$ & $\begin{array}{c}136 \\
-75.18\end{array}$ & $\begin{array}{c}136 \\
-74.11\end{array}$ \\
\hline
\end{tabular}

Mixed effects results reported, with random effects on session and sender.

Standard errors in parentheses; all regressions include a constant term.

Period 1 observations dropped from analysis; only observations in jury

treatments and where ripoff occurred included; *** $\mathrm{p}<0.01,{ }^{* *} \mathrm{p}<0.05,{ }^{*} \mathrm{p}<0.1$

Table 5: Mixed Effects Linear Probability Estimates Explaining the Decision to Dispute, Jury Treatments

such cases the sender is 20 percentage points less likely to file a dispute, all else equal.

Result 7: The likelihood that a cheated sender will file a dispute is strongly increasing in the degree to which she was ripped off. The presence of information-sharing does not affect the likelihood of filing.

Given that a dispute is filed, it is also important to know what factors influence juries' decisions. Table 6 reports mixed effects linear probability estimates of the decision to convict 
the receiver. ${ }^{11}$ Here we report two specifications, one of which controls for treatment differences and one of which includes additional independent variables accounting for the direct effects of past actions that would be public knowledge only in the Jury - Info treatment. Again, the coefficient on variable measuring the magnitude of the violation is positive and significant. Here we cannot distinguish between motivations behind jury votes. It is possible that voters are motivated by the desire to protect their group's reputation and to encourage future exchange, but purely altruistic motivations are equally plausible.

\begin{tabular}{lcc}
\hline Action Taken By: & \multicolumn{2}{c}{ Receiver's Group } \\
Dependent Variable & Sender Won Dispute $(0 / 1)$ \\
\hline Jury-Info & -0.190 & -0.285 \\
& $(0.187)$ & $(0.215)$ \\
Inverse Period & -0.092 & -0.025 \\
$\left(\frac{1}{t}\right)$ & $(0.205)$ & $(0.224)$ \\
Sent & -0.032 & -0.024 \\
(amt. sent by S) & $(0.027)$ & $(0.027)$ \\
Ripoff Magnitude & $0.034^{* * *}$ & $0.030^{* *}$ \\
((message \% amt. received from S) - amt. returned by R) & $(0.012)$ & $(0.012)$ \\
Pvs. Ripoff of Group, Same * Info & & 0.372 \\
(fraction of pvs. times R's group members ripped off S's group * info) & & $(0.289)$ \\
Pvs. Conviction, Group * Jury * Info & & -0.114 \\
(\# of trials members of R's group convicted * jury * info) & & $(0.098)$ \\
Previous Acquittal, Group * Jury * Info & & 0.098 \\
(\# of trials members of R's group acquitted * jury * info) & & $(0.078)$ \\
Constant & & $0.663^{* *}$ \\
& & $(0.259)$ \\
\hline Observations & $0.715^{* * *}$ & 86 \\
Log Likelihood & $(0.251)$ & -56.22 \\
\hline $\begin{array}{l}\text { Mixed effects results reported, with random effects on session. } \\
\text { Standard errors in parentheses; all regressions include a constant term. }\end{array}$ \\
$\begin{array}{l}\text { Period 1 dropped from analysis; only observations in jury treatments and } \\
\text { where dispute occurred included; *** p }<0.01, * * \text { p }<0.05, * \text { p }<0.1\end{array}$ \\
\hline
\end{tabular}

Table 6: Mixed Effects Linear Probability Estimates Explaining Jury's Decisions to Convict, Jury Treatments

Similarly, we report in the Appendix (Table A1) results of regressions exploring individuals' voting patterns. Column (1) reports a regression for the Jury - No Info and Jury - Info treatments where the dependent variable takes a value of 1 if the voter chose to convict and

\footnotetext{
${ }^{11}$ These regressions differ from the previous ones in that we include random effects only at the session level, since jury voting is a collective decision.
} 
0 otherwise. Here too, we find that the decision to convict is influenced by the magnitude of the ripoff, and we find that individual differences are an important driver of behavior. Those who voted to convict in the past are more likely to do so again, although convictions become less likely the more times individuals are asked to vote. We find no evidence that information-sharing influences voting decisions.

Result 8: At both the group and individual level, the rate of conviction is increasing in the difference between the amount offered by the receiver and the amount actually returned. Information-sharing does not impact voting.

\subsection{Robustness check: Paying to Vote}

As a stress test on the effectiveness of the jury mechanism, we conducted a treatment denoted Jury - Info - Pay in which prospective members of the jury could opt-in to jury service at a cost of $2 \mathrm{ECU} /$ vote. This treatment provides a setting in which upholding group reputation through the jury mechanism is costly. In the other treatments, there is no direct penalty for voting.

Returning to Table 1, we see that in terms of amount sent, amount returned, percent returned, and probability of ripping off the sender, the Jury - Info - Pay treatment is nearly indistinguishable from the Jury - Info treatment. In Appendix A (Tables A2 and A3), we report the results of regressions similar to those in Tables 3 and 4, but including the Pay treatment. The results are essentially the same as those in the Jury - Info treatment, with the exception that the negative impact of acquittals on amount sent is slightly mitigated in the Pay treatment. There is no difference in the amount returned, although receivers who have previously been acquitted return slightly less in the Pay treatment. These results suggest that despite the increased cost of appeals to the jury, there is no increase in the rate or magnitude of broken promises. 


\begin{tabular}{|c|c|c|c|}
\hline $\begin{array}{l}\text { Action taken by: } \\
\text { Dependent Variable }\end{array}$ & \multicolumn{3}{|c|}{$\begin{array}{c}\text { Sender } \\
\text { Dispute }(0 / 1)\end{array}$} \\
\hline Jury-Info & $\begin{array}{l}-0.120 \\
(0.090)\end{array}$ & $\begin{array}{l}-0.133 \\
(0.090)\end{array}$ & $\begin{array}{r}-0.143^{*} \\
(0.086)\end{array}$ \\
\hline Jury-Info-Pay & $\begin{array}{c}-0.207^{* *} \\
(0.097)\end{array}$ & $\begin{array}{c}-0.209^{* *} \\
(0.096)\end{array}$ & $\begin{array}{c}-0.234^{* *} \\
(0.099)\end{array}$ \\
\hline $\begin{array}{l}\text { Inverse Period } \\
\left(\frac{1}{t}\right)\end{array}$ & $\begin{array}{l}-0.051 \\
(0.116)\end{array}$ & $\begin{array}{l}-0.125 \\
(0.133)\end{array}$ & $\begin{array}{l}-0.126 \\
(0.132)\end{array}$ \\
\hline $\begin{array}{l}\text { Sent } \\
\text { (amt. sent by } \mathrm{S})\end{array}$ & $\begin{array}{c}0.003 \\
(0.014)\end{array}$ & $\begin{array}{l}-0.001 \\
(0.014)\end{array}$ & $\begin{array}{c}0.014 \\
(0.017)\end{array}$ \\
\hline $\begin{array}{l}\text { Ripoff Amount } \\
\left(\left(\text { message } \%^{*} \text { amt. received from } S\right)-\text { amt. returned by } \mathrm{R}\right)\end{array}$ & $\begin{array}{c}0.043^{* * *} \\
(0.007)\end{array}$ & $\begin{array}{c}0.046^{* * *} \\
(0.007)\end{array}$ & $\begin{array}{c}0.037^{* * *} \\
(0.009)\end{array}$ \\
\hline $\begin{array}{l}\text { Pvs. Ripoff } \\
\text { (fraction of pvs. pds. S ripped off by R's group) }\end{array}$ & & $\begin{array}{l}-0.121 \\
(0.105)\end{array}$ & $\begin{array}{l}-0.105 \\
(0.107)\end{array}$ \\
\hline $\begin{array}{l}\text { Pvs. Win * Pay } \\
\text { (\# of pvs. trials won by S vs R's group * pay) }\end{array}$ & & & $\begin{array}{c}0.274 \\
(0.171)\end{array}$ \\
\hline $\begin{array}{l}\text { Pvs. Lose * Pay } \\
\text { (\# of pvs. trials won by S vs R's group * pay) }\end{array}$ & & & $\begin{array}{l}-0.076 \\
(0.125)\end{array}$ \\
\hline $\begin{array}{l}\text { Better Than Autarky * Ripoff } \\
\text { (equals } \mathbf{1} \text { if } 10-\text { amt. sent }+ \text { amt. returned }>10 \text {, equals } \mathbf{0} \text { otherwise) }\end{array}$ & & & $\begin{array}{r}-0.151^{*} \\
(0.088)\end{array}$ \\
\hline Constant & $\begin{array}{c}0.468^{* * *} \\
(0.129)\end{array}$ & $\begin{array}{c}0.547^{* * *} \\
(0.145)\end{array}$ & $\begin{array}{c}0.541^{* * *} \\
(0.143)\end{array}$ \\
\hline \multicolumn{4}{|l|}{ Wald Test $p$-values } \\
\hline Jury-Info = Jury-Info-Pay & 0.384 & 0.530 & 0.560 \\
\hline Observations & 197 & 197 & 197 \\
\hline Log Likelihood & -115.4 & -114.7 & -112.1 \\
\hline
\end{tabular}

Table 7: Mixed Effects Linear Probability Estimates Explaining the Decision to Dispute, Jury and Pay Treatments

One likely difference between the Jury - Info and Jury - Info - Pay treatments is in the likelihood of filing and of winning disputes in case of ripoffs. ${ }^{12}$ To determine whether these differences are statistically significant and to understand the origins of any such differences, Table 7 reports mixed effects linear probability estimates where the dependent variable takes a value of 1 when a sender who was ripped off chose to employ the Jury mechanism and 0 otherwise. In column (1), the independent variables are treatment dummy variables (Jury No Info is the baseline), a period trend, the amount sent, the magnitude of the ripoff, and

\footnotetext{
${ }^{12}$ In one Jury - Info - Pay session, no receiver ever returned less than offered, so this analysis is based on additional data from two sessions.
} 
a constant term. The coefficient on the Jury - Info - Pay treatment dummy is negative and significant, but this coefficient is not significantly different than the one on the Jury-Info treatment $(\mathrm{p}=0.384)$. This suggests that introducing a cost to upholding group reputation has no significant effect on the sender's decision to sue, all else equal. In columns (2) and (3), we include additional variables meant to account for path dependence, and we interact them with the Pay treatment. As in the Jury treatments without Pay, we find no evidence of significant path dependence, though the estimated coefficient on the "better than autarky" dummy is negative and significant. In neither case are the coefficients on the Jury - Info and Jury - Info - Pay treatments significantly different.

Result 9: The sender's decision to sue does not change significantly when receivers have to pay to opt-in to the jury mechanism, all else equal.

Table 8 reports mixed effects linear probability estimates of the decision to convict the receiver in the Jury - No Info, Jury - Info, and Jury - Info - Pay treatments. Here we again investigate the impact of the Pay treatment as well as its interaction with variables designed to account for path dependence. As before, a positive and significant coefficient on the ripoff magnitude indicates that the likelihood of winning the dispute is sensitive to the extent of the violation. In column (2), when we include variables for path dependence, the estimated coefficient on the Pay treatment is negative and significant. Yet a Wald test cannot reject the null hypothesis that the coefficients on the Jury - Info and Jury - Info - Pay treatments are equal. ${ }^{13}$

Result 10: There are no statistically significant differences in the conviction rate in the Jury - Info and Jury - Info - Pay treatments, all else equal.

\footnotetext{
${ }^{13}$ Column (2) of Table A1 in Appendix A reports the output of similar regressions explaining individuals' decisions to convict. Here we also find that conviction decisions are sensitive to the magnitude of the ripoff. However we observe no treatment difference. As before, voters who have convicted in the past are more likely to do so in the future, but the rate of conviction declines slightly with the number of times an individual votes.
} 


\begin{tabular}{|c|c|c|}
\hline \multirow{2}{*}{$\begin{array}{l}\text { Action Taken By: } \\
\text { Dependent Variable }\end{array}$} & \multicolumn{2}{|c|}{$\begin{array}{c}(1) \\
\text { Receiver's Group } \\
\text { Sender Won Dispute }(0 / 1)\end{array}$} \\
\hline & $\begin{array}{l}-0.163 \\
(0.199)\end{array}$ & $\begin{array}{l}-0.207 \\
(0.210)\end{array}$ \\
\hline Jury-Info-Pay & $\begin{array}{l}-0.347 \\
(0.236)\end{array}$ & $\begin{array}{r}-0.495^{*} \\
(0.263)\end{array}$ \\
\hline $\begin{array}{l}\text { Inverse period } \\
\left(\frac{1}{t}\right)\end{array}$ & $\begin{array}{l}-0.070 \\
(0.181)\end{array}$ & $\begin{array}{c}0.084 \\
(0.205)\end{array}$ \\
\hline $\begin{array}{l}\text { Sent } \\
\text { (amt. sent by } \mathrm{S})\end{array}$ & $\begin{array}{l}-0.023 \\
(0.021)\end{array}$ & $\begin{array}{l}-0.013 \\
(0.021)\end{array}$ \\
\hline $\begin{array}{l}\text { Ripoff Magnitude } \\
((\text { message } \% * \text { amt. received from } \mathrm{S}) \text { - amt. returned by } \mathrm{R})\end{array}$ & $\begin{array}{c}0.024^{* *} \\
(0.010)\end{array}$ & $\begin{array}{l}0.019^{*} \\
(0.010)\end{array}$ \\
\hline $\begin{array}{l}\text { Pvs. Ripoff of Group, Same * Info } \\
\text { (fraction of pvs. times R's group members ripped off S's group * info) }\end{array}$ & & $\begin{array}{c}0.162 \\
(0.219)\end{array}$ \\
\hline $\begin{array}{l}\text { Pvs. Conviction, Group * Jury * Info } \\
(\# \text { of trials members of R's group convicted } * \text { jury } * \text { info })\end{array}$ & & $\begin{array}{l}-0.089 \\
(0.091)\end{array}$ \\
\hline $\begin{array}{l}\text { Previous Acquittal, Group * Jury * Info } \\
(\# \text { of trials members of R's group acquitted } * \text { jury } * \text { info })\end{array}$ & & $\begin{array}{c}0.111 \\
(0.075)\end{array}$ \\
\hline $\begin{array}{l}\text { Previous Conviction, Group } * \text { Jury } * \text { Pay } \\
(\# \text { of trials members of R's group convicted } * \text { jury } * \text { pay })\end{array}$ & & $\begin{array}{r}0.329^{* *} \\
(0.142)\end{array}$ \\
\hline $\begin{array}{l}\text { Previous Acquittal, Group } * \text { Jury * Pay } \\
\text { (\# of trials members of R's group acquitted } * \text { jury } * \text { pay) }\end{array}$ & & $\begin{array}{l}-0.089 \\
(0.091)\end{array}$ \\
\hline Constant & $\begin{array}{c}0.699^{* * *} \\
(0.226)\end{array}$ & $\begin{array}{c}0.603^{* * *} \\
(0.229)\end{array}$ \\
\hline \multicolumn{3}{|l|}{ Wald Test $p$-values } \\
\hline Jury-Info = Jury-Info-Pay & 0.378 & 0.233 \\
\hline Observations & 115 & 115 \\
\hline Log Likelihood & -75.33 & -71.83 \\
\hline
\end{tabular}

Table 8: Mixed Effects Linear Probability Estimates Explaining Jury's Decisions to Convict, Jury and Pay Treatments

\section{Conclusions}

Our experiment highlights the crucial role of both information-sharing and in-group punishment in sustaining group reputation and facilitating exchange. While in-group punishment reduces the likelihood of cheating, information sharing accentuates path-dependence since individuals can condition their behavior not only on their own prior experiences but also on the experiences of others in their group. This generates strong complementarities between the two mechanisms, since the punishment mechanism puts groups on a more favorable path 
and information sharing causes positive feedback from a mutually beneficial history. While we explore these mechanisms in the context of a single experimental environment, the underlying issues are important to a variety of contexts, many of which were discussed in detail in the introduction. Indeed, our results suggest a primary reason why many modern and historical institutions combine these elements.

Our work is also related to research on the effects of identity on economic behavior (see e.g. Akerlof and Kranton, 2000). In recent experiments, Chen and Chen (2011) demonstrated that a salient group identity can facilitate cooperation among members of a group. Another important function of group identity is found in the fact that it increases incentives to maintain the group's reputation, since one's own identity is tied to others' perceptions of the group. In this case, by inducing group identity, we might be able to further increase the gains from exchange. However, it is also possible that stronger group identities will lead to differential treatment of in- and out-group members, as in Chen and Li (2009), perhaps leading to a trade off of increased trade within the group against increased cheating outside the group. We do not explore these possibilities here, since aside from randomly assigning individuals to groups labeled by different colors, we make no effort to induce identity. However, we suggest this as a fruitful avenue for future research.

\section{References}

Akerlof, George A., and Rachel E. Kranton (2000) 'Economics and identity.' Quarterly Journal of Economics 115(3), 715-753

Balliet, Daniel (2010) 'Communication and cooperation in social dilemmas: A meta-analytic review.' Journal of Conflict Resolution 54(1), 39-57

Bar-Isaac, Heski (2007) 'Something to prove: reputation in teams.' The RAND Journal of Economics 38(2), 495-511

Ben-Ner, Avner, and Louis Putterman (2009) 'Trust, communication and contracts: An experiment.' Journal of Economic Behavior \& Organization 70(1â'“2), 106 - 121 
Berg, J., J. Dickhaut, and K. McCabe (1995) 'Trust, reciprocity, and social history.' Games and economic behavior 10(1), 122-142

Besley, Timothy, and Stephen Coate (1995) 'Group lending, repayment incentives and social collateral.' Journal of development economics 46(1), 1-18

Boerner, Lars, and Albrecht Ritschl (2009) 'The economic history of sovereignty: communal responsibility, the extended family, and the firm.' Journal of Institutional and Theoretical Economics 165(1), 99-112

Bohnet, Iris, and Steffen Huck (2004) 'Repetition and reputation: Implications for trust and trustworthiness when institutions change.' American Economic Review pp. 362-366

Bohnet, Iris, and Yael Baytelman (2007) 'Institutions and trust: Implications for preferences, beliefs and behavior.' Rationality and Society 19(1), 99-135

Cain, Bruce E, John A Ferejohn, and Morris P Fiorina (1987) The personal vote: Constituency service and electoral independence (Harvard University Press Cambridge, MA)

Cassar, A., D. Friedman, and P.H. Schneider (2009) 'Cheating in markets: A laboratory experiment.' Journal of Economic Behavior 83 Organization 72(1), 240-259

Cassar, Alessandra, Daniel Friedman, and Patricia Higino Schneider (2010) 'A laboratory investigation of networked markets.' The Economic Journal 120(547), 919-943

Charness, Gary, and Martin Dufwenberg (2006) 'Promises and partnership.' Econometrica $74(6), 1579-1601$

Chen, Roy, and Yan Chen (2011) 'The potential of social identity for equilibrium selection.' American Economic Review 101(6), 2562-2589

Chen, Yan, and Sherry Xin Li (2009) 'Group identity and social preferences.' American Economic Review 99(1), 431-457

Cooper, David J., and John Kagel (2013) 'Other regarding preferences: A selective survey of experimental results.' forthcoming in The Handbook of Experimental Economics, Vol. 2, eds. Kagel, J. and Roth, A.

Cunliffe, Barry W. (2008) Europe Between the Oceans: 9000 BC to AD 1000 (New Haven: Yale University Press)

de Aghion, Beatriz Armendáriz (1999) 'On the design of a credit agreement with peer monitoring.' Journal of Development Economics 60(1), 79 - 104

Dixit, Avinash K (2004) Lawlessness and economics: alternative modes of governance (Princeton University Press) 
Evans, Robert Andrew, and Timothy W. Guinnane (2007) 'Collective reputation, professional regulation and franchising.' Cowles Foundation Discussion Paper No. 1627. Available at SSRN: http://ssrn.com/abstract=1015104

Fearon, James D, and David D Laitin (1996) 'Explaining interethnic cooperation.' American Political Science Review pp. 715-735

Fudenberg, Drew, and Eric S. Maskin (1986) 'The folk theorem in repeated games with discounting or with incomplete information.' Econometrica 54, 533-554

Ghatak, Maitreesh, and Timothy W Guinnane (1999) 'The economics of lending with joint liability: theory and practice.' Journal of development economics 60(1), 195-228

Ghosh, Parikshit, and Debraj Ray (1996) 'Cooperation in community interaction without information flows.' The Review of Economic Studies 63(3), 491-519

Greif, Avner (1993) 'Contract enforceability and economic institutions in early trade: The maghribi traders' coalition.' The American Economic Review pp. 525-548

_ (2000) 'The fundamental problem of exchange: a research agenda in historical institutional analysis.' European Review of Economic History 4(03), 251-284

_ (2002) 'Institutions and impersonal exchange: from communal to individual responsibility.' Journal of Institutional and Theoretical Economics (JITE)/Zeitschrift für die gesamte Staatswissenschaft pp. 168-204

_ (2004) 'Impersonal exchange without impartial law: the community responsibility system.' Chicago Journal International Law 5, 109

_ (2006) Institutions and the Path to the Modern Economy: Lessons from Medieval Trade (Political Economy of Institutions and Decisions) (Cambridge University Press)

Greif, Avner, Paul Milgrom, and Barry R. Weingast (1994) 'Coordination, commitment, and enforcement: The case of the merchant guild.' Journal of political economy pp. 745-776

Healy, Paul J. (2007) 'Group reputations, stereotypes, and cooperation in a repeated labor market.' American Economic Review 97(5), 1751-1773

Huck, Steffen, and Gabriele K. Lünser (2010) 'Group reputations: An experimental foray.' Journal of Economic Behavior $\&$ Organization 73(2), 153 - 157

Kandori, Michihiro (1992) 'Social norms and community enforcement.' Review of Economic Studies 59(1), 63-80

Katz, Jonathan N., and Brian R. Sala (1996) 'Careerism, committee assignments, and the electoral connection.' The American Political Science Review 90(1), pp. 21-33 
Kranton, Rachel E (1996) 'Reciprocal exchange: A self-sustaining system.' The American Economic Review pp. 830-851

Levin, Jonathan (2009) 'The dynamics of collective reputation.' The B.E. Journal of Theoretical Economics

Levinson, Daryl J (2003) 'Collective sanctions.' Stanford Law Review pp. 345-428

McIntosh, Craig, Elisabeth Sadoulet, Steven Buck, and Tomas Rosada (forthcoming) 'Reputation in a public goods game: Taking the design of credit bureaus to the lab.' Journal of Economic Behavior $\&$ Organization

Milgrom, Paul R., Douglass C. North, and Barry R. Weingast (1990) 'The role of institutions in the revival of trade: The law merchant, private judges, and the champagne fairs.' Economics \& Politics 2(1), 1-23

R Development Core Team (2012) R: A Language and Environment for Statistical Computing R Foundation for Statistical Computing (Vienna, Austria). ISBN 3-900051-07-0

Richardson, Gary (2005) 'Craft guilds and christianity in late-medieval england a rationalchoice analysis.' Rationality and society 17(2), 139-189

Richardson, Gary, and Michael McBride (2009) 'Religion, longevity, and cooperation: The case of the craft guild.' Journal of Economic Behavior \& Organization 71(2), 172-186

Seabright, Paul (1993) 'Managing local commons: Theoretical issues in incentive design.' The Journal of Economic Perspectives 7(4), pp. 113-134

Tirole, Jean (1996) 'A theory of collective reputations (with applications to the persistence of corruption and to firm quality).' The Review of Economic Studies 63(1), 1-22

Winfree, Jason A, and Jill J McCluskey (2005) 'Collective reputation and quality.' American Journal of Agricultural Economics 87(1), 206-213 


\section{Appendix}

\section{A Additional Regression Tables}

\begin{tabular}{|c|c|c|}
\hline \multirow[b]{2}{*}{ Jury-Info } & \multicolumn{2}{|c|}{$\begin{array}{l}(1) \quad(2) \\
\text { Convict }(1 / 0)\end{array}$} \\
\hline & $\begin{array}{l}-0.188 \\
(0.131)\end{array}$ & $\begin{array}{l}-0.203 \\
(0.138)\end{array}$ \\
\hline Pay & & $\begin{array}{l}-0.123 \\
(0.247)\end{array}$ \\
\hline Period & $\begin{array}{c}0.007 \\
(0.017)\end{array}$ & $\begin{array}{c}0.004 \\
(0.017)\end{array}$ \\
\hline Amt Sent - Amount Returned & $\begin{array}{c}0.017^{* * *} \\
(0.006)\end{array}$ & $\begin{array}{c}0.017^{* * *} \\
(0.006)\end{array}$ \\
\hline Previous Conviction Count & $\begin{array}{c}0.139^{* * *} \\
(0.022)\end{array}$ & $\begin{array}{c}0.127^{* * *} \\
(0.023)\end{array}$ \\
\hline Previous Vote Count & $\begin{array}{c}-0.075^{* * *} \\
(0.016)\end{array}$ & $\begin{array}{c}-0.068^{* * *} \\
(0.016)\end{array}$ \\
\hline Previous Convictions by Group Members * Jury * Info & $\begin{array}{l}-0.052 \\
(0.049)\end{array}$ & $\begin{array}{l}-0.041 \\
(0.048)\end{array}$ \\
\hline Previous Acquittals by Group Members * Jury * Info & $\begin{array}{c}0.042 \\
(0.043)\end{array}$ & $\begin{array}{c}0.045 \\
(0.043)\end{array}$ \\
\hline Previous Convictions by Group Members * Pay & . & $\begin{array}{c}0.045 \\
(0.117)\end{array}$ \\
\hline Previous Acquittals by Group Members * Pay & . & $\begin{array}{c}0.019 \\
(0.124)\end{array}$ \\
\hline Allocation Better than Autarky & $\begin{array}{c}0.048 \\
(0.070)\end{array}$ & $\begin{array}{c}0.036 \\
(0.067)\end{array}$ \\
\hline Constant & $\begin{array}{c}0.605^{* * *} \\
(0.118)\end{array}$ & $\begin{array}{c}0.624^{* * *} \\
(0.122)\end{array}$ \\
\hline $\begin{array}{l}\text { Observations } \\
\text { Log Likelihood }\end{array}$ & $\begin{array}{c}258 \\
-155.4\end{array}$ & $\begin{array}{c}274 \\
-165.0\end{array}$ \\
\hline
\end{tabular}

Table A1: Mixed Effects Regressions Explaining Individual Votes, Jury and Pay treatments 


\begin{tabular}{|c|c|c|c|}
\hline & (1) & $(2)$ & (3) \\
\hline $\begin{array}{l}\text { Action taken by: } \\
\text { Dependent Variable: }\end{array}$ & \multicolumn{3}{|c|}{$\begin{array}{c}\text { Sender } \\
\text { Amount Sent }\end{array}$} \\
\hline Jury-Info & $\begin{array}{l}-0.044 \\
(0.498)\end{array}$ & $\begin{array}{l}-0.059 \\
(0.522)\end{array}$ & $\begin{array}{l}1.218^{* *} \\
(0.504)\end{array}$ \\
\hline Pay & $\begin{array}{c}0.389 \\
(0.557)\end{array}$ & $\begin{array}{c}0.281 \\
(0.602)\end{array}$ & $\begin{array}{c}0.914 \\
(0.572)\end{array}$ \\
\hline $\begin{array}{l}\text { Inverse Period } \\
\left(\frac{1}{t}\right)\end{array}$ & $\begin{array}{c}0.040 \\
(0.888)\end{array}$ & $\begin{array}{l}-0.532 \\
(0.896)\end{array}$ & $\begin{array}{r}-1.953^{* *} \\
(0.907)\end{array}$ \\
\hline $\begin{array}{l}\text { Message * Message Sent } \\
\text { (message } \% * \text { message dummy) }\end{array}$ & $\begin{array}{c}14.893^{* * *} \\
(1.059)\end{array}$ & $\begin{array}{c}15.678^{* * *} \\
(1.066)\end{array}$ & $\begin{array}{c}16.879^{* * *} \\
(1.027)\end{array}$ \\
\hline $\begin{array}{l}\text { No Message } \\
\text { (no message dummy) }\end{array}$ & $\begin{array}{c}2.480^{* * *} \\
(0.656)\end{array}$ & $\begin{array}{c}2.846^{* * *} \\
(0.657)\end{array}$ & $\begin{array}{c}3.371^{* * *} \\
(0.630)\end{array}$ \\
\hline $\begin{array}{l}\text { Avg. Sent Pvs. } \\
\left(\frac{\sum_{t=1}^{t-1} \text { sent } t}{t-1}\right)\end{array}$ & $\begin{array}{c}0.283^{* * *} \\
(0.060)\end{array}$ & $\begin{array}{c}0.282^{* * *} \\
(0.060)\end{array}$ & $\begin{array}{c}0.243^{* * *} \\
(0.058)\end{array}$ \\
\hline $\begin{array}{l}\text { Pvs Ripoff, Same } \\
\text { (fraction of pvs. pds. S ripped off by R's group) }\end{array}$ & $\begin{array}{c}-1.653^{* * *} \\
(0.385)\end{array}$ & $\begin{array}{l}-0.400 \\
(0.484)\end{array}$ & $\begin{array}{l}-0.263 \\
(0.466)\end{array}$ \\
\hline $\begin{array}{l}\text { Pvs Ripoff, Other } \\
\text { (fraction of pvs. pds. S ripped off by other (not R's) group) }\end{array}$ & $\begin{array}{l}-0.563 \\
(0.419)\end{array}$ & & \\
\hline $\begin{array}{l}\text { Pvs. Win * Jury } \\
\text { (\# of pvs. trials won by S vs. R's group * jury dummy) }\end{array}$ & & $\begin{array}{c}-0.786^{* *} \\
(0.376)\end{array}$ & $\begin{array}{l}-0.398 \\
(0.366)\end{array}$ \\
\hline $\begin{array}{l}\text { Pvs. Win * Pay } \\
\text { (\# of pvs. trials won by S vs. R's group * pay dummy) }\end{array}$ & & $\begin{array}{l}1.453 \\
(0.904)\end{array}$ & $\begin{array}{l}1.038 \\
(0.883)\end{array}$ \\
\hline $\begin{array}{l}\text { Pvs. Lose }{ }^{*} \text { Jury } \\
\text { (\# of pvs. trials lost by S vs. R's group * jury dummy) }\end{array}$ & & $\begin{array}{l}-0.853^{* * *} \\
(0.307)\end{array}$ & $\begin{array}{c}-0.792^{* * *} \\
(0.297)\end{array}$ \\
\hline $\begin{array}{l}\text { Pvs. Lose * Pay } \\
\text { (\# of pvs. trials lost by S vs. R's group * pay dummy) }\end{array}$ & & $\begin{array}{l}-0.357 \\
(0.487)\end{array}$ & $\begin{array}{c}0.169 \\
(0.555)\end{array}$ \\
\hline $\begin{array}{l}\text { Pvs. Ripoff of Group * Info } \\
\text { (fraction of pvs. times others in S's group ripped of by R's group * info) }\end{array}$ & & & $\begin{array}{r}-1.481^{* *} \\
(0.651)\end{array}$ \\
\hline $\begin{array}{l}\text { Pvs. Wins of Group * Jury * Info } \\
\text { (\# of pvs. trials won by others in S's group vs. R's group * jury * info) }\end{array}$ & & & $\begin{array}{r}-0.448^{*} \\
(0.238)\end{array}$ \\
\hline $\begin{array}{l}\text { Pvs. Wins of Group * Pay } \\
\text { (\# of pvs. trials won by others in S's group vs. R's group * pay) }\end{array}$ & & & $\begin{array}{c}0.439 \\
(0.380)\end{array}$ \\
\hline $\begin{array}{l}\text { Pvs. Losses of Group * Jury * Info } \\
\text { (\# of pvs. trials lost by others in S's group vs. R's group * jury * info) }\end{array}$ & & & $\begin{array}{c}-1.253^{* * *} \\
(0.214)\end{array}$ \\
\hline $\begin{array}{l}\text { Pvs. Losses of Group *Pay } \\
\text { (\# of pvs. trials lost by others in S's group vs. R's group * pay) }\end{array}$ & & & $\begin{array}{c}0.893^{* * *} \\
(0.284)\end{array}$ \\
\hline Constant & $\begin{array}{r}-1.495^{*} \\
(0.781)\end{array}$ & $\begin{array}{c}-1.801^{* *} \\
(0.774)\end{array}$ & $\begin{array}{c}-1.937^{* * *} \\
(0.734)\end{array}$ \\
\hline $\begin{array}{l}\text { Observations } \\
\text { Log Likelihood }\end{array}$ & $\begin{array}{c}792 \\
-2011.8\end{array}$ & $\begin{array}{c}792 \\
-2004.9\end{array}$ & $\begin{array}{c}792 \\
-1966.6\end{array}$ \\
\hline
\end{tabular}

Table A2: Mixed Effects Regressions Explaining the Amount Sent, Jury and Pay Treatments 


\begin{tabular}{|c|c|c|c|}
\hline \multirow[b]{2}{*}{$\begin{array}{l}\text { Action taken by: } \\
\text { Dependent Variable: }\end{array}$} & (1) & (2) & (3) \\
\hline & \multicolumn{3}{|c|}{$\begin{array}{c}\text { Receiver } \\
\text { Returned \% - Message \% }\end{array}$} \\
\hline Jury-Info & $\begin{array}{l}-0.007 \\
(0.020)\end{array}$ & $\begin{array}{l}-0.007 \\
(0.018)\end{array}$ & $\begin{array}{c}0.011 \\
(0.020)\end{array}$ \\
\hline Pay & $\begin{array}{l}-0.028 \\
(0.022)\end{array}$ & $\begin{array}{l}-0.015 \\
(0.021)\end{array}$ & $\begin{array}{l}-0.000 \\
(0.023)\end{array}$ \\
\hline $\begin{array}{l}\text { Inverse Period } \\
\left(\frac{1}{t}\right)\end{array}$ & $\begin{array}{c}-0.143^{* * *} \\
(0.035)\end{array}$ & $\begin{array}{c}-0.144^{* * *} \\
(0.035)\end{array}$ & $\begin{array}{c}-0.141^{* * *} \\
(0.036)\end{array}$ \\
\hline $\begin{array}{l}\text { Sent } \\
\text { (amt. Sent by S) }\end{array}$ & $\begin{array}{l}-0.003 \\
(0.002)\end{array}$ & $\begin{array}{r}-0.003^{*} \\
(0.002)\end{array}$ & $\begin{array}{r}-0.003^{*} \\
(0.002)\end{array}$ \\
\hline $\begin{array}{l}\text { Avg. Returned - Message Pvs. } \\
\left(\frac{\sum_{t=1}^{t-1} \% \text { returned }-\% \text { message }}{t-1}\right)\end{array}$ & $\begin{array}{l}0.604^{* * *} \\
(0.030)\end{array}$ & $\begin{array}{l}0.590^{* * *} \\
(0.035)\end{array}$ & $\begin{array}{c}0.577^{* * *} \\
(0.035)\end{array}$ \\
\hline $\begin{array}{l}\text { Pvs. Ripoff } \\
\text { (fraction of pvs. pds. R ripped off one in S's group) }\end{array}$ & $\begin{array}{c}-0.059^{* * *} \\
(0.015)\end{array}$ & $\begin{array}{c}-0.048^{* * *} \\
(0.015)\end{array}$ & $\begin{array}{l}-0.022 \\
(0.016)\end{array}$ \\
\hline $\begin{array}{l}\text { Pvs. Conviction } * \text { Jury } \\
(\# \text { of pvs. trials convicted } * \text { jury) }\end{array}$ & & $\begin{array}{r}0.024^{* *} \\
(0.011)\end{array}$ & $\begin{array}{l}0.019^{*} \\
(0.011)\end{array}$ \\
\hline $\begin{array}{l}\text { Pvs. Acquittal } * \text { Jury } \\
(\# \text { of pvs. trials acquitted } * \text { jury })\end{array}$ & & $\begin{array}{l}-0.014 \\
(0.013)\end{array}$ & $\begin{array}{l}-0.019 \\
(0.013)\end{array}$ \\
\hline $\begin{array}{l}\text { Pvs. Conviction } * \text { Pay } \\
(\# \text { of pvs. trials convicted } * \text { pay })\end{array}$ & & $\begin{array}{l}-0.011 \\
(0.024)\end{array}$ & $\begin{array}{l}-0.026 \\
(0.033)\end{array}$ \\
\hline $\begin{array}{l}\text { Pvs. Acquittal } * \text { Pay } \\
(\# \text { of pvs. trials acquitted } * \text { pay })\end{array}$ & & $\begin{array}{c}-0.052^{* * *} \\
(0.019)\end{array}$ & $\begin{array}{c}-0.058^{* *} \\
(0.025)\end{array}$ \\
\hline $\begin{array}{l}\text { Pvs. Ripoff of Group, Same * Info } \\
\text { (fraction of prior times others in R's group ripped off S's group * info) }\end{array}$ & & & $\begin{array}{c}-0.103^{* * *} \\
(0.032)\end{array}$ \\
\hline $\begin{array}{l}\text { Pvs. Conviction, Group } * \text { Jury } * \text { Info } \\
\text { (\# of trials other members of R's group convicted } * \text { jury } * \text { info) }\end{array}$ & & & $\begin{array}{l}0.008 \\
(0.009)\end{array}$ \\
\hline $\begin{array}{l}\text { Pvs. Acquittal, Group * Jury * Info } \\
\text { (\# of trials other members of R's group acquitted } * \text { jury } * \text { info) }\end{array}$ & & & $\begin{array}{l}-0.004 \\
(0.010)\end{array}$ \\
\hline $\begin{array}{l}\text { Pvs. Conviction, Group * Pay } \\
\text { (\# of trials other members of R's group convicted * pay) }\end{array}$ & & & $\begin{array}{c}0.017 \\
(0.017)\end{array}$ \\
\hline $\begin{array}{l}\text { Pvs. Acquittal, Group * Pay } \\
\text { (\# of trials other members of R's group acquitted * pay) }\end{array}$ & & & $\begin{array}{c}0.009 \\
(0.012)\end{array}$ \\
\hline Constant & $\begin{array}{c}0.076^{* * *} \\
(0.023)\end{array}$ & $\begin{array}{c}0.071^{* * *} \\
(0.022)\end{array}$ & $\begin{array}{c}0.066^{* * *} \\
(0.023)\end{array}$ \\
\hline Observations & 619 & 619 & 619 \\
\hline Log Likelihood & 537.1 & 549.2 & 556.0 \\
\hline
\end{tabular}

Table A3: Mixed Effects Regressions Explaining the Percent Returned - Percent Promised, Jury and Pay Treatments 


\section{B Experiment Instructions}

Below we include instructions for each treatment. Each page of the instructions is labeled in the order subjects saw it in the experiment, and next to the page number we indicate which instructions were shown in which treatments. Any words surrounded by "@” symbols indicate parameters that were automatically filled by the experiment software and may have been specific to the subject.

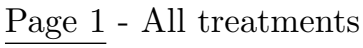

You are now participating in a decision making experiment. If you follow the instructions carefully, you can earn a considerable amount of money depending on your decisions and the decisions of the other participants. Your earnings will be paid to you in CASH at the end of the experiment

This set of instructions is for your private use only. During the experiment you are not allowed to communicate with anybody. If you have any questions, please raise your hand, and an experimenter will come to your seat and answer them privately. Any violation of this rule excludes you immediately from the experiment and all payments.

This experiment will consist of several periods.

In this experiment, there will be two groups of people, Red and Blue. Each group is composed of 8 people, divided into two types, Senders and Receivers. In total there are 4 Red Senders, 4 Red Receivers, 4 Blue Senders, and 4 Blue Receivers.

You are a@myColor@@myPlayerType@.

At the beginning of each period you will be randomly paired with either a Red or Blue @partnerPlayerType@. You will never be paired with another@myPlayerType@.

\section{Page 2 - All treatments}

Each Sender begins each period with 10 Experimental Currency Units (ECUs). A Sender may choose to send none, any, or all of these ECUs to the Receiver he/she is paired with by typing the amount into a box in the center of the screen and then clicking "Send".

Any ECUs that a Sender sends to a Receiver will be subtracted from the Sender's account, multiplied by 3 and transferred to the Receiver. Any ECUs that a Sender chooses not to send to the Receiver remain the Sender's earnings. (Only Senders will be able to send ECUs and have them multiplied.)

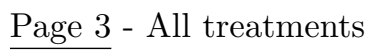


Each Receiver enters a period with 10 ECUs.

After the Sender makes a decision, the Receiver will see how many ECUs were sent by the Sender.

The amount sent by the Sender will be multiplied by 3 and added to the Receiver's account. Then the Receiver decides to send none, any or all of these ECUs to the Sender by typing the amount into a box in the center of the screen and then clicking "Send". (Only Receivers will make this decision.)

$\underline{\text { Page } 4}$ - All treatments

A Message

However, before the Sender decides how many ECUs to send to the Receiver, each Receiver will have the opportunity to send a message to the Sender.

All messages read:

"I will return X\% of the total amount that I receive."

Note that the total ECUs received is equal to $3 \mathrm{x}$ ECUs sent. When the percentage is computed, the number is rounded up (i.e. 14.4 becomes 15).

And the Receiver can either: 1) choose $\mathrm{X}$ to be an integer between 0 and 100 and click the button labeled Send Message, or 2) click the button labeled No Message.

If the Receiver chooses to send a message, the Sender will read the message prior to making his decision, and if the Receiver chooses No Message, then the Sender will see a message that reads:

"The Receiver has chosen not to send a message."

$\underline{\text { Page } 5}$ - All treatments

In each period, each Receiver is paired with one Sender for the entire period. (One "period" consists of one Message, one Sender deciding how many ECUs to send to one Receiver and that Receiver deciding how many of the multiplied ECUs to send to the paired Sender.)

Example: If the Receiver offers to return $60 \%$ of the ECUs received, and the Sender sends 8 ECUs, then to fulfill the offer, the Receiver would send at least 15 ECUs back to receiver $(0.6 * 8$ ECUs $* 3=14.4$, rounded up to 15).

$\underline{\text { Page } 6}$ - All treatments 
Earnings

After each player has finished making decisions, you will receive detailed feedback on the outcome of the period.

A Sender's earnings for a period are:

Earnings $=$ Starting ECUs

minus Amount Sent to Receiver

plus Amount Sent from Receiver

A Receiver's earnings for a period are:

Earnings $=$ Starting ECUs

plus Amount Sent by Sender x 3

minus Amount Sent to Sender

$\underline{\text { Page } 7}$ - NoJury-Info, Jury-NoInfo, Jury-Info, and Pay treatments

After all decisions have been made, you will see a table displaying the results for other@myPlayerType@s in your group. Specifically, for each other@YourColor@@myPlayerType@ you will see:

1. The color of the @partnerPlayerType@ with whom they interacted

2. The message they sent/received (or No Message if a message wasn't sent)

3. How many ECUs were sent to the Receiver

4. The amount the Receiver would need to send back to fulfill the message they sent (if they sent a message)

5. How many ECUs were sent to the Sender

6. Their earnings for the period.

$\underline{\text { Page } 8}$ - Jury-NoInfo and Jury-Info treatments

If the Receiver does not fulfill the offer, then the Sender will have the opportunity to pay a cost of @disputeCost@ ECUs to Dispute the outcome. If no message was sent or the Receiver fulfilled the offer, then no Dispute is possible.

If a Sender chooses to Dispute the outcome, then all other Receivers of the same color as the Receiver he/she is paired with will decide on the outcome of the Dispute. Specifically, each other Receiver of the same color will review the details of the dispute and then Vote whether to require the Receiver to Fulfill the offer.

If a majority votes Fulfill: 
1. The Receiver will pay to the Sender the difference between the amount he/she originally sent to the Sender and the amount indicated in the message.

2. The Receiver will pay @disputeCost@ ECUs to the Sender.

If a majority votes Do Not Fulfill:

1. The Sender receives no additional ECUs.

If more than one Sender chooses to Dispute the outcome in a single period, the order of Disputes will be random.

\section{Page 8 Alternate - Pay treatment}

Under the History Table, each Sender will receive information indicating whether the Receiver fulfilled the offer as indicated in the message (by returning at least as much as was indicated in the message). If the Receiver does not fulfill the offer, then the Sender will have the opportunity to pay a cost of @disputeCost@ ECUs to Dispute the outcome. If no message was sent or the Receiver fulfilled the offer, then no Dispute is possible.

If a Sender chooses to Dispute the outcome, then all other Receivers of the same color as the Receiver he/she is paired with will decide whether to Vote or Abstain. Receivers who choose to Vote will pay a cost of@voteCost@ and then will vote on the outcome of the Dispute. Specifically, each other Receiver of the same color who chooses to Vote will review the details of the dispute and then Vote whether to require the Receiver to Fulfill the offer. If multiple disputes occur in a single period, each Receiver will choose whether to Vote or Abstain only once.

If a majority of those voting votes Fulfill:

1. The Receiver will pay to the Sender the difference between the amount he/she originally sent to the Sender and the amount indicated in the message.

2. The Receiver will pay @disputeCost@ECUs to the Sender.

If a majority of those voting votes Do Not Fulfill:

1. The Sender receives no additional ECUs.

If more than one Sender chooses to Dispute the outcome in a single period, the order of Disputes will be random.

If all vote to Abstain, then the Receiver will not be required to Fulfill the offer.

If an equal amount vote FULFILL and NOT FULFILL, then the outcome will be decided with a computerized coin flip. 
$\underline{\text { Page } 9}$ - Jury-NoInfo and Jury-Info treatments

Example: Continuing the example from earlier (in which the Receiver offers to return $60 \%$ of the amount received), suppose the Sender sends 8 ECUs (which multiply into 24 ECUs), and the Receiver returns 10 ECUs. In this case, the amount returned is less than $60 \%$ of the amount received (15 ECUs), so the Sender can choose to dispute the outcome for @disputeCost@ ECUs. Then, the other Receivers of the same color as the disputed Receiver will vote whether to require the offer to be fulfilled. On the other hand, if the Receiver returns 15 or more ECUs, the Sender cannot dispute the outcome. If the other Receivers vote to require that the offer is fulfilled, then the Receiver must pay the Sender a 5 ECU payment of the difference between the promised amount (15 ECUs) and the returned amount (10 ECUs), as well as an additional @disputeCost@ ECUs.

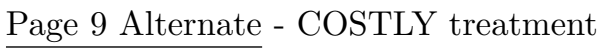

Example: Continuing the example from earlier (in which the Receiver offers to return $60 \%$ of the amount received), suppose the Sender sends 8 ECUs (which multiply into 24 ECUs), and the Receiver returns 10 ECUs. In this case, the amount returned is less than $60 \%$ of the amount received (15 ECUs), so the Sender can choose to dispute the outcome for @disputeCost@ECUs. Then, the other Receivers of the same color as the disputed Receiver will decide whether to Vote or Abstain. Those that choose to Vote will pay a cost of @voteCost@ and then vote whether to require the offer to be fulfilled. On the other hand, if the Receiver returns 15 or more ECUs, the Sender cannot dispute the outcome. If the other Receivers vote to require that the offer is fulfilled, then the Receiver must pay the Sender a 5 ECU payment of the difference between the promised amount (15 ECUs) and the returned amount (10 ECUs), as well as an additional @disputeCost@ ECUs.

\section{$\underline{\text { Page } 10}$ - All treatments}

After each period, you will review the results and click "Continue". The period will begin when all players have clicked "Continue".

At the end of the experiment the sum of your ECUs from all periods will be converted to dollars at a rate of @exchangeRate@ ECUs = 1 Dollar and paid to you privately in cash, plus $\$ 7$ for arriving to the experiment on time.

This is the end of the instructions. If you have any questions please raise your hand and an experimenter will come by to answer them. 


\section{Time Remaining: 0 Seconds}

Period 1

You are Blue Receiver 1.

You are matched with a Blue Sender.

Any money that the Blue Sender chooses to send to you will be multiplied by $\mathbf{3}$, and then you will have the opportunity to return NONE, ANY, or ALL of that amount to the Sender.

Before the Sender makes a decision, you may pass a message to the Sender that says:

"I will return $\mathbf{X} \%$ of the total amount that I receive."

If you want to send a message, type any value of $\mathbf{X}$ between 0 and 100 into the box below and click the SEND button. If you do not want to send a message, then click the NO MESSAGE button.

\section{Send}

Return

37 $\%$

No Message

Figure B1: Screen Shot of Receiver's Message Decision. 


\section{Time Remaining: 22 Seconds}

\section{Period 1}

\section{You are Red Receiver 1.}

The Red Sender sent you $\mathbf{2}$ ECU. The amount was multiplied by $\mathbf{3}$, so you received 6 ECU.

You offered to return $\mathbf{2 2} \%$ of the amount you received, which in this case is $\mathbf{2} \mathbf{E C U}$. However, you can return NONE, ANY, or ALL of the amount you received.

When you decide how much you want to return to the Red Sender, type the amount into the box below and click Send.

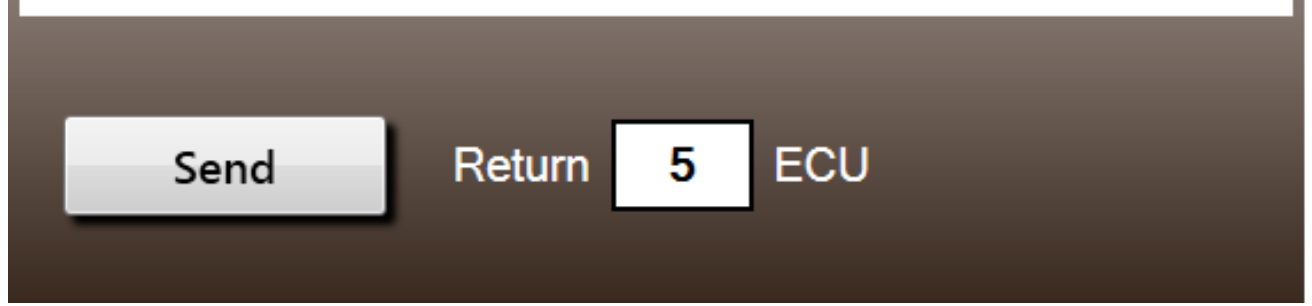

Figure B2: Screen Shot of Receiver's Return Decision. 


\section{Time Remaining: 36 Seconds}

\section{Period 1}

You are Blue Receiver 1.

One or more Red/Blue Sender(s) has chosen to Dispute the outcome of their interaction with a Blue Receiver.

You can choose to VOTE or ABSTAIN during the dispute(s) to follow.

If you choose to VOTE, you must pay $2 \mathrm{ECU}$, and you will be able to vote in all of the Disputes involving a Blue Receiver except for disputes that you are a part of.

If there is only one dispute and you are a part of it, then you will not pay $2 \mathrm{ECU}$ even if you choose VOTE. You will also not be able vote.

If you choose to ABSTAIN, you will neither be charged nor be able to vote in any Dispute.

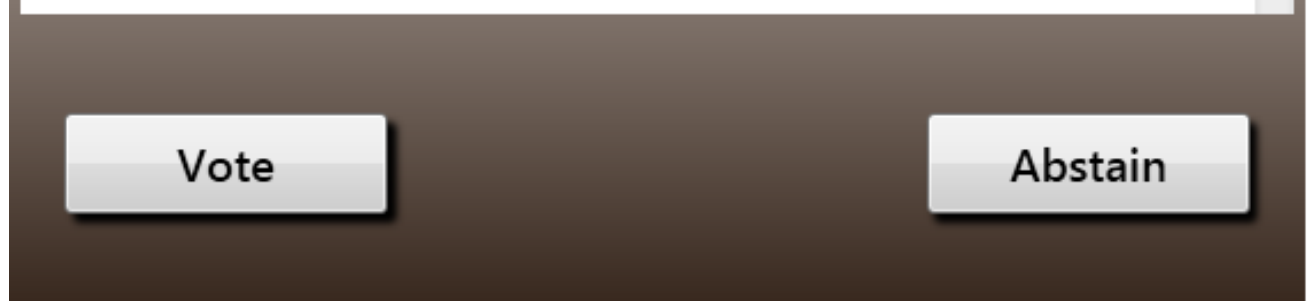

Figure B3: Screen Shot of Vote Decision. 
2013

\section{Economic Science Institute Working Papers}

13-13 Moore, K., Sun, P., de Vries, C., and Zhou, C. Shape Homogeneity and Scale Heterogeneity of Downside Tail Risk.

13-12 Chowdhury, S., Lee, D., and Sheremeta, R. Top Guns May Not Fire: Best-Shot Group Contests with Group-Specific Public Good Prizes.

13-11 Kimbrough, E., Rubin, J., Sheremeta, R., Shields, T. Commitment Problems in Conflict $\underline{\text { Resolution. }}$

13-10 Klose, B. and Kovenock, D. The All-Pay Auction with Complete Information and Identity-Dependent Externalities.

13-09 Branas-Garza, P., Kovarik, J., and Neyse, L. Second-to-Fourth Digit Ratio has a NonMonotonic Impact on Altruism.

13-08 McCarter, M., Samak, A., and Sheremeta, R. Divided Loyalties or Conditional Cooperation? An experimental study of contributions to multiple public goods.

13-07 Gabaix, X., Laibson, D., Li, D., Li, H., Resnick, S., and de Vries, C. The Impact of Competition on Prices with Numerous Firms.

13-06 Sheremeta, R. Overbidding and Heterogeneous Behavior in Contest Experiments.

13-05 Deck, C. and Porter, D. Prediction Markets in the Laboratory.

13-04 Corgnet, B., Hernán-Gonzalez, R., Kujal, P., and Porter, D. The Effect of Earned vs. House Money on Price Bubble Formation in Experimental Asset Markets.

13-03 Sheremeta, R. and Zhang, J. Three-Player Trust Game with Insider Communication.

13-02 McCarter, M. and Sheremeta, R. You Can't Put Old Wine in New Bottles: The Effect of Newcomers on Coordination in Groups.

13-01 Corgnet, B., Hernan-Gonzalez, R., and Rassenti, S. Peer Pressure and Moral Hazard in Teams: Experimental Evidence.

\section{2}

12-31 Thomas, C. An Alternating-Offers Model of Multilateral Negotiations.

12-30 Mago, S., Sheremeta, R. and Yates, A. Best-of-Three Contest Experiments: Strategic versus psychological momentum. 
12-29 Bigoni, M., Camera, G. and Casari, M. Strategies of Cooperation and Punishment among Students and Clerical Workers.

12-28 Camera, G. and Kim, J. Buyer's Equilibrium with Capacity Constraints and Restricted Mobility: A recursive approach.

12-27 Camera, G., Casari, M., and Bigoni, M. Binding Promises and Cooperation Among Strangers.

12-26 Schniter, E., Shields, T. and Dickhaut, J. Ageism \& Cooperation.

12-25 Gjerstad, S. and Smith, V. Balance Sheet Crises: Causes, Consequences and Responses.

12-24 Gómez-Miñambres, J., Corgnet, B. and Hernán-Gonzalez, R. Goal Setting and Monetary Incentives: When Large Stakes Are Not Enough.

12-23 Clots-Figueras, I., Hernán González, R., and Kujal, P. Asymmetry and Deception in the Investment Game.

12-22 Dechenaux, E., Kovenock, D. and Sheremeta, R. A Survey of Experimental Research on Contests, All-Pay Auctions and Tournaments.

12-21 Rubin, J. and Sheremeta, R. Principal-Agent Settings with Random Shocks.

12-20 Gómez-Miñambres, J. and Schniter, E. Menu-Dependent Emotions and Self-Control.

12-19 Schniter, E., Sheremeta, R., and Sznycer, D. Building and Rebuilding Trust with Promises and Apologies.

12-18 Shields, T. and Xin, B. Higher-order Beliefs in Simple Trading Models.

12-17 Pfeiffer, G. and Shields, T. Performance-Based Compensation and Firm Value: Experimental evidence.

12-16 Kimbrough, E. and Sheremeta, R. Why Can't We Be Friends? Entitlements, bargaining, and conflict.

12-15 Mago, S., Savikhin, A., and Sheremeta, R. Facing Your Opponents: Social identification and information feedback in contests.

12-14 McCarter, M., Kopelman, S., Turk, T. and Ybarra, C. Too Many Cooks Spoil the Broth: How the tragedy of the anticommons emerges in organizations.

12-13 Chowdhury, S., Sheremeta, R. and Turocy, T. Overdissipation and Convergence in Rent-seeking Experiments: Cost structure and prize allocation rules. 
12-12 Bodsky, R., Donato, D., James, K. and Porter, D. Experimental Evidence on the Properties of the California's Cap and Trade Price Containment Reserve.

12-11 Branas-Garza, P., Espin, A. and Exadaktylos, F. Students, Volunteers and Subjects: Experiments on social preferences.

12-10 Klose, B. and Kovenock, D. Extremism Drives Out Moderation.

12-09 Buchanan, J. and Wilson, B. An Experiment on Protecting Intellectual Property.

12-08 Buchanan, J., Gjerstad, S. and Porter, D. Information Effects in Multi-Unit Dutch Auctions.

12-07 Price, C. and Sheremeta, R. Endowment Origin, Demographic Effects and Individual Preferences in Contests.

12-06 Magoa, S. and Sheremeta, R. Multi-Battle Contests: An experimental study.

12-05 Sheremeta, R. and Shields, T. Do Liars Believe? Beliefs and Other-Regarding Preferences in Sender-Receiver Games.

12-04 Sheremeta, R., Masters, W. and Cason. T. Winner-Take-All and Proportional-Prize Contests: Theory and experimental results.

12-03 Buchanan, J., Gjerstad, S. and Smith, V. There's No Place Like Home.

12-02 Corgnet, B. and Rodriguez-Lara, I. Are you a Good Employee or Simply a Good Guy? Influence Costs and Contract Design.

12-01 Kimbrough, E. and Sheremeta, R. Side-Payments and the Costs of Conflict.

\section{1}

11-20 Cason, T., Savikhin, A. and Sheremeta, R. Behavioral Spillovers in Coordination Games.

11-19 Munro, D. and Rassenti, S. Combinatorial Clock Auctions: Price direction and performance.

11-18 Schniter, E., Sheremeta, R., and Sznycer, D. Restoring Damaged Trust with Promises, Atonement and Apology.

11-17 Brañas-Garza, P., and Proestakis, A. Self-discrimination: A field experiment on obesity.

11-16 Brañas-Garza, P., Bucheli, M., Paz Espinosa, M., and García-Muñoz, T. Moral Cleansing and Moral Licenses: Experimental evidence.

11-15 Caginalp, G., Porter, D., and Hao, L. Asset Market Reactions to News: An experimental study.

11-14 Benito, J., Branas-Garz, P., Penelope Hernandez, P., and Sanchis Llopis, J. Strategic Behavior in Schelling Dynamics: A new result and experimental evidence. 
11-13 Chui, M., Porter, D., Rassenti, S. and Smith, V. The Effect of Bidding Information in Ascending Auctions.

11-12 Schniter, E., Sheremeta, R. and Shields, T. Conflicted Minds: Recalibrational emotions following trust-based interaction.

11-11 Pedro Rey-Biel, P., Sheremeta, R. and Uler, N. (Bad) Luck or (Lack of) Effort?: Comparing social sharing norms between US and Europe.

11-10 Deck, C., Porter, D., and Smith, V. Double Bubbles in Assets Markets with Multiple Generations.

11-09 Kimbrough, E., Sheremeta, R., and Shields, T. Resolving Conflicts by a Random Device.

11-08 Brañas-Garza, P., García-Muñoz, T., and Hernan, R. Cognitive effort in the Beauty Contest Game.

11-07 Grether, D., Porter, D., and Shum, M. Intimidation or Impatience? Jump Bidding in On-line Ascending Automobile Auctions.

11-06 Rietz, T., Schniter, E., Sheremeta, R., and Shields, T. Trust, Reciprocity and Rules.

11-05 Corgnet, B., Hernan-Gonzalez, R., and Rassenti, S. Real Effort, Real Leisure and Real-time Supervision: Incentives and peer pressure in virtual organizations.

11-04 Corgnet, B. and Hernán-González R. Don’t Ask Me If You Will Not Listen: The dilemma of participative decision making.

11-03 Rietz, T., Sheremeta, R., Shields, T., and Smith, V. Transparency, Efficiency and the Distribution of Economic Welfare in Pass-Through Investment Trust Games.

11-02 Corgnet, B., Kujal, P. and Porter, D. The Effect of Reliability, Content and Timing of Public Announcements on Asset Trading Behavior.

11-01 Corgnet, B., Kujal, P. and Porter, D. Reaction to Public Information in Markets: How much does ambiguity matter?

\section{0}

10-23 Sheremeta, R. Perfect-Substitutes, Best-Shot, and Weakest-Link Contests between Groups.

10-22 Mago, S., Sheremeta, R., and Yates, A. Best-of-Three Contests: Experimental evidence.

10-21 Kimbrough, E. and Sheremeta, R. Make Him an Offer He Can't Refuse: Avoiding conflicts through side payments.

10-20 Savikhim, A. and Sheremeta, R. Visibility of Contributions and Cost of Inflation: An experiment on public goods.

10-19 Sheremeta, R. and Shields, T. Do Investors Trust or Simply Gamble? 
10-18 Deck, C. and Sheremeta, R. Fight or Flight? Defending Against Sequential Attacks in the Game of Siege.

10-17 Deck, C., Lin, S. and Porter, D. Affecting Policy by Manipulating Prediction Markets: Experimental evidence.

10-16 Deck, C. and Kimbrough, E. Can Markets Save Lives? An Experimental Investigation of a Market for Organ Donations.

10-15 Deck, C., Lee, J. and Reyes, J. Personality and the Consistency of Risk Taking Behavior: Experimental evidence.

10-14 Deck, C. and Nikiforakis, N. Perfect and Imperfect Real-Time Monitoring in a Minimum-Effort Game.

10-13 Deck, C. and Gu, J. Price Increasing Competition? Experimental Evidence.

10-12 Kovenock, D., Roberson, B., and Sheremeta, R. The Attack and Defense of Weakest-Link Networks.

10-11 Wilson, B., Jaworski, T., Schurter, K. and Smyth, A. An Experimental Economic History of Whalers' Rules of Capture.

10-10 DeScioli, P. and Wilson, B. Mine and Thine: The territorial foundations of human property.

10-09 Cason, T., Masters, W. and Sheremeta, R. Entry into Winner-Take-All and Proportional-Prize Contests: An experimental study.

10-08 Savikhin, A. and Sheremeta, R. Simultaneous Decision-Making in Competitive and Cooperative Environments.

10-07 Chowdhury, S. and Sheremeta, R. A generalized Tullock contest.

10-06 Chowdhury, S. and Sheremeta, R. The Equivalence of Contests.

10-05 Shields, T. Do Analysts Tell the Truth? Do Shareholders Listen? An Experimental Study of Analysts' Forecasts and Shareholder Reaction.

10-04 Lin, S. and Rassenti, S. Are Under- and Over-reaction the Same Matter? A Price Inertia based Account.

10-03 Lin, S. Gradual Information Diffusion and Asset Price Momentum.

10-02 Gjerstad, S. and Smith, V. Household Expenditure Cycles and Economic Cycles, 1920 - 2010.

10-01 Dickhaut, J., Lin, S., Porter, D. and Smith, V. Durability, Re-trading and Market Performance. 
09-11 Hazlett, T., Porter, D., and Smith, V. Radio Spectrum and the Disruptive Clarity OF Ronald Coase.

09-10 Sheremeta, R. Expenditures and Information Disclosure in Two-Stage Political Contests.

09-09 Sheremeta, R. and Zhang, J. Can Groups Solve the Problem of Over-Bidding in Contests?

09-08 Sheremeta, R. and Zhang, J. Multi-Level Trust Game with "Insider" Communication.

09-07 Price, C. and Sheremeta, R. Endowment Effects in Contests.

09-06 Cason, T., Savikhin, A. and Sheremeta, R. Cooperation Spillovers in Coordination Games.

09-05 Sheremeta, R. Contest Design: An experimental investigation.

09-04 Sheremeta, R. Experimental Comparison of Multi-Stage and One-Stage Contests.

09-03 Smith, A., Skarbek, D., and Wilson, B. Anarchy, Groups, and Conflict: An experiment on the emergence of protective associations.

09-02 Jaworski, T. and Wilson, B. Go West Young Man: Self-selection and endogenous property rights.

09-01 Gjerstad, S. Housing Market Price Tier Movements in an Expansion and Collapse.

\section{8}

08-09 Dickhaut, J., Houser, D., Aimone, J., Tila, D. and Johnson, C. High Stakes Behavior with Low Payoffs: Inducing preferences with Holt-Laury gambles.

08-08 Stecher, J., Shields, T. and Dickhaut, J. Generating Ambiguity in the Laboratory.

08-07 Stecher, J., Lunawat, R., Pronin, K. and Dickhaut, J. Decision Making and Trade without Probabilities.

08-06 Dickhaut, J., Lungu, O., Smith, V., Xin, B. and Rustichini, A. A Neuronal Mechanism of Choice.

08-05 Anctil, R., Dickhaut, J., Johnson, K., and Kanodia, C. Does Information Transparency Decrease Coordination Failure?

08-04 Tila, D. and Porter, D. Group Prediction in Information Markets With and Without Trading Information and Price Manipulation Incentives.

08-03 Thomas, C. and Wilson, B. Horizontal Product Differentiation in Auctions and Multilateral Negotiations.

08-02 Oprea, R., Wilson, B. and Zillante, A. War of Attrition: Evidence from a laboratory experiment on market exit. 
08-01 Oprea, R., Porter, D., Hibbert, C., Hanson, R. and Tila, D. Can Manipulators Mislead Prediction Market Observers? 